\title{
Household Regulation and European Integration: The Family Portrait of a Crisis
}

Philomila Tsoukala

Georgetown University Law Center, pt96@law.georgetown.edu

This paper can be downloaded free of charge from:

https://scholarship.law.georgetown.edu/facpub/1380

http://ssrn.com/abstract=2504106

Am. J. Comp. L. (forthcoming 2014)

This open-access article is brought to you by the Georgetown Law Library. Posted with permission of the author. Follow this and additional works at: https://scholarship.law.georgetown.edu/facpub

Part of the Business Law, Public Responsibility, and Ethics Commons, Comparative and Foreign Law Commons, European Law Commons, and the Law and Economics Commons 


\title{
Household Regulation and European Integration: The Family Portrait of a CRISIS
}

\author{
Philomila Tsoukala* \\ Georgetown University Law Center \\ pt96@law.georgetown.edu \\ (202) 662-4041
}

***Draft accepted for publication by the American Journal of Comparative Law-Please contact the author before citing or quoting the current version***

Keywords

Household, family, European crisis, Greece, sovereign debt crisis, welfare, family business, structural reforms, European Semester

\author{
Category \\ European Law
}

\footnotetext{
* Associate Professor of Law, Georgetown University Law Center. I would like to thank Kerry Abrams, Karen Engle, Janet Halley, Allegra McLeod, Naomi Mezey, Sherally Munshi, Alvaro Santos, Fred Schauer, Richard Schragger, Mike Seidman, Pierre-Hugues Verdier, Emiliana Versteeg, Robin West for insightful comments and questions. The article also profited from questions and comments by participants in the faculty workshop at the University of Virginia School of Law and Georgetown University Law Center.
} 


\begin{abstract}
This Article develops a theoretical framework for analyzing the regulation of the household and its effects on the economy. Incorporating insights from family economics, comparative family law, legal realism, political economy and feminism, it describes the array of different legal regimes that can affect household composition and function. The Article then analyzes the case of Greece using this framework. It argues that the role of households organized as families was a central element in the Greek debt crisis, overlooked by scholars and policymakers alike. It identifies the host of legal regimes that helped consolidate families as the main providers of both welfare and employment and analyzes the consequences of this organization for Greece's economy. Finally, the Article argues that a household based analysis offers useful comparative insights in the context of the euro crisis and its management. More specifically, it elucidates how the structural reforms now required through the European Semester necessitate a dramatic transformation of basic schemes of welfare provisioning. It argues that without additional support these transformations are likely to fail or have dramatic unintended consequences.
\end{abstract}


TABLE OF CONTENTS



I. THEORIZING THE ECONOMIC HOUSEHOLD AND ITS REGULATION ................................................... 6

A. The economic household or "there and back again" ..............................................................6

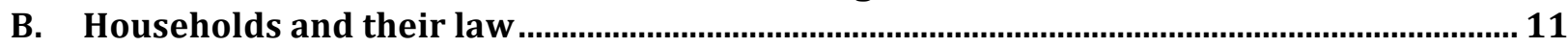

II. HoUSEHOLD REGULATION AND EUROPEAN INTEGRATION: THE GREEK CASE ..................................14

A. Captured State, Ottoman Citizens and A Puzzle ................................................................ 14

B. Pre-accession economic and regulatory background .......................................................... 16

C. Post-accession regulatory background and its effect on households.................................. 19

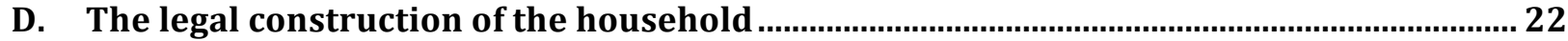

E. Revisiting the Greek crisis through the lens of household strategies ............................... 24

III. COMPARATIVE IMPLICATIONS: HOUSEHOLD REGULATION AND EUROPEAN INTEGRATION IN CRISIS 30

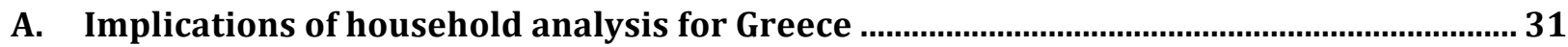



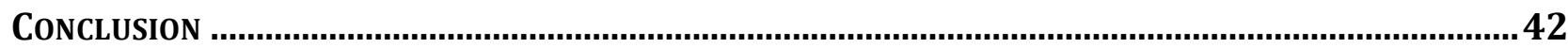

\section{INTRODUCTION}

In the spring of 2010, Greece's brush with bankruptcy caused global financial panic. Academics, pundits, and policy makers scrambled for an explanation. Explanations very quickly centered on the Greek state's seemingly endless need to borrow in order to sustain a wasteful public sector. ${ }^{1}$ European and even Greek politicians pointed the finger at the Greeks' allegedly generous welfare entitlements. ${ }^{2}$ Some openly accused the Greeks of having a lax working culture, in contrast to the hard working European north. ${ }^{3}$ Greece avoided an open default with a

\footnotetext{
${ }^{1}$ European and Greek politicians initially used this narrative with their domestic constituencies. See, e.g., German Chancellor on the Offensive: Merkel Blasts Greece over Retirement Age, Vacation, SPIEGEL ONLINE (May 18, 2011), http://www.spiegel.de/international/europe/german-chancellor-on-the-offensive-merkel-blasts-greece-overretirement-age-vacation-a-763294.html; Tony Barber, Greece Plays the Ethical Blame Game, FIN. TIMES (June 21, 2011), http://www.ft.com/intl/cms/s/0/42d88b20-9c1f-11e0-acbc-00144feabdc0.html (describing how Greek politician Theodoros Pangalos, then vice-President of the government said all Greeks were to blame for the debt problem because they "ate" the money together); Raffaela Giordano et. al., The Public Sector Pay Gap in a Selection of Euro Area Countries (European Cent. Bank, Working Paper No. 1406, 2011), http://www.ecb.europa.eu/pub/pdf/scpwps/ecbwp1406.pdf (explaining the benefits public sector employees in Greece enjoy as compared to their counterparts in other European countries, including lifetime contracts and protections from termination); John Sfakianakis, Op-Ed., The Cost of Protecting Greece's Public Sector, N.Y. TiMES, Oct. 10, 2012, http://www.nytimes.com/2012/10/11/opinion/the-cost-of-protecting-greeces-publicsector.html ("Wages in the public sector were on average almost one and half times higher than in the private sector.").

${ }^{2}$ Tony Barber, supra note 1.

${ }^{3}$ The German Finance Minister was quoted as saying: "Greece needs to do its own homework to become competitive ... We're happy to help but we shouldn't give others the feeling that they don't have to work [sic] hard
} 
huge loan from its euro area partners and the IMF, on condition of dramatic austerity and deep structural reforms. ${ }^{4}$ The reforms were designed, according to the European Commission, to deal with Greece's trade imbalance in the short term, and improve Greece's growth prospects in the long term. ${ }^{5}$

Absent from the discussion on what caused the crisis and what reforms were needed, however, was any discussion of a crucial part of Greek social organization: the Greek family. This, despite the fact that the Greek family was the big elephant in the room of economic woes. The Greek family business provided one of the main forms of employment in the private sector. ${ }^{6}$ Furthermore, by contrast to misleading depictions of a generous welfare state with ample benefits for workers, it was the Greek family that provided the main means of welfare to dependents, filling holes for an unreliable state and a sagging labor market. ${ }^{7}$ Even employment in the public sector was often accessed through mechanisms of family networking. ${ }^{8}$ So accepted was familism that politics itself was-and still is- practiced as a family business. ${ }^{9}$ Nonetheless, the institutional accounts of the crisis focused on competitiveness issues based in labor market "rigidities" perpetuated by "vested interests", ${ }^{10}$ while other accounts propagated a problematic narrative of a "culture of informality" and a "culture of tax evasion.",11

Following the intuition that something monumental was being lost in any description of Greece's woes that left the family out of the picture I wrote an op-ed, in which I sketched a brief picture of the Greek family's economic role. ${ }^{12}$ I argued that rather than dismantling welfare through cutbacks or obsessing about imagined labor rigidities in a market characterized by ultra flexible family businesses, the reforms should focus on putting in place a welfare regime able to provide alternatives to the almost exclusive role of the family in the provisioning of basic

themselves. Every country is responsible for itself." Erik Kirschbaum, Schaeuble Warns Greek Promises No Longer Suffice, REUTERS (Feb. 12, 2012), http://www.reuters.com/article/2012/02/12/us-germany-greeceidUSTRE81B05N20120212 (quoting Vol Olaf Gersemann \& Jan Hildebrand, Davon geht die Welt nicht unter, WELT AM SONNTAG (July 29, 2012), http://www.welt.de/print/wams/wirtschaft/article108407703/Davon-geht-dieWelt-nicht-unter.html).

${ }^{4}$ See Philomila Tsoukala, Narratives of the European Crisis and the Future of (Social) Europe, 48 TEX. INT'L L.J. 241, 241-66 (2013).

${ }^{5}$ See generally European Comm'n, The Economic Adjustment Programme for Greece (May 26, 2010 ), 21 - 22,79 80, http://ec.europa.eu/economy_finance/publications/occasional_paper/2010/pdf/ocp61_en.pdf.

${ }^{6}$ See discussion infra Section IID.

${ }^{7}$ See, e.g., Neovi M. Karakatsanis, Relying on Stop-Gap Measures: Coping with Unemployment in Greece, 4 S. EUR. SOC'Y \& POL., no. 3, 1999 at 240-262; Theano Kallinikaki, Gender, Children and Families in the Greek Welfare State, in CHILDREN, GENDER AND FAMILIES IN MEDITERRANEAN WELFARE STATES 181, 181-202 (Mimi Ajzenstadt \& John Gal eds., Springer 2010).

${ }^{8}$ Theo Papadopoulos \& Antonios Roumpakis, Familistic Welfare Capitalism in Crisis: The Case of Greece, (ERI Working Paper Series, Working Paper No. 09-14, 2009).

${ }^{9}$ When Greece signed its 2010 loan agreement with its euro partners and the IMF, a third generation Papandreou was prime minister succeeding yet another Karamanlis in the preceding years. The party clientelist relations of Greek politicians were often further mediated by family relations. Linette Lopez, The Political Dynasties That Destroyed Greece, And The Real Reason The Country Is Such A Mess, Bus. InSIDER, July 5, 2011, http://www.businessinsider.com/greeces-political-dynasties-the-reason-for-the-crises-2011-7\#ixzz33JIeRIou.

10 European Comm'n, The Second Economic Adjustment Programme for Greece (March 2012), 9, http://ec.europa.eu/economy_finance/publications/occasional_paper/2012/pdf/ocp94_en.pdf [hereinafter EAPGR2].

${ }^{11}$ Nikolaos Artavanis et al., Tax Evasion Across Industries: Soft Credit Evidence from Greece, (Chicago Booth Research Paper, Working Paper No. 12-25, 2012).

12 Philomila Tsoukala, Op-Ed., A Family Portrait of a Greek Tragedy, N.Y. TIMES,Apr. 25, 2010,http://www.nytimes.com/2010/04/25/opinion/25tsoukala.html. 
welfare and even employment to dependents. ${ }^{13}$ After publishing the piece I realized that part of the reason it resonated with many people- including the New York Times' editors who picked itwas that it seemed to echo a misleading cultural narrative already present as an explanatory narrative device of the crisis. Suddenly, the idea of a culture supposedly lagging behind modernity made a sneaky reappearance, in my op-ed. It is an idea as old as the creation of the modern Greek state and one which has trapped Greek citizens into turning every single reform question into an impossible existential calculus: tradition or modernity.

This Article further develops the intuition that familism was central in the country's problems. ${ }^{14}$ However, it puts familism back in its place. It develops an analysis of familism as a policy choice, one that was developed and consolidated through a multitude of legal and regulatory choices. Rather than juxtaposing a supposedly compact culture to the distinct field of the economy, or a supposedly insular Greek culture to Europe, the Article describes the dynamic process through which individual agents' preferences interacting with structural constraints, domestic and European, produced the Greek family as a major force in the country's social and economic organization. The 'culture' of Greek familism that supposedly reflects Greek tradition is in fact the contingent result of European integration in the last forty years. As a dynamic process it is much more contingent and movable than one imagines when first confronted with the idea of choices shaped by a complex interaction between structural constraints and individual preferences. $^{15}$

Consequently, one of the main aspirations of the Article is to provide an alternative picture of the crisis, one that is increasingly relevant for the broader European context. Recently, euro area governance has drawn inspiration from the loan conditionality of bailout countries, incorporating desirable reforms for everyone. ${ }^{16}$ To the extent that Greece's basic structure for providing welfare resembles other systems in the European south, where austerity and structural reforms are also pursued, Greece provides a useful cautionary tale for what can go wrong when basic welfare mechanisms are destroyed without any compensatory mechanism put in place.

The Article's broader theoretical aspiration is to contribute to the literature, or rather series of literatures that attempt to put the household and the family in a continuum with the economy. ${ }^{17}$ Households are a central, even though regularly overlooked, part of market economies performing basic economic functions in a continuous and mutually constitutive

\footnotetext{
${ }^{13} I d$.

${ }^{14}$ In this article, I do not discuss but take for granted that the most convincing explanations for the breakout of the Greek sovereign debt crisis have to do with the factors that are related to the structure of euro zone and to its governance. See, e.g., Paul De Grauwe, The Governance of a Fragile Eurozone, 45 AustL. ECON. REV. 255,255 - 68 (2012). For more discussion, see Philomila Tsoukala, Euro Zone Crisis Management and the New Social Europe, 20 ColuM. J. EUR. L. 31, 31 - 76 (2013). I also take for granted that there were internal Greek factors that contributed towards making the Greek economy the weakest link in the European periphery. This article aims to develop the insight that the Greek family was both an effective welfare mechanism and a contributing factor in Greek inefficiencies.

${ }^{15}$ Determining causation is a very complicated issue. Culture and economic incentives are intricately intertwined and the argument here is not that one is necessarily the primary mover, but that they mutually influenced each other over the course of more than thirty years. In the case of Greece, culture has been overemphasized to the detriment of incentives. This is even more so in the domain of family law. This article aspires to serve as a corrective to the purely cultural narratives about causation so prevalent in the academic as well popular press.

${ }^{16}$ Philomila Tsoukala, Euro Zone Crisis Management and the New Social Europe, 20 COLUM. J. EUR. L. 31 , 31 - 76 (2013).

${ }^{17}$ See discussion infra Section I.
} 
regulatory relationship to markets. The Article draws from literatures as diverse as comparative family law, legal realism, comparative welfarism, household economics, and anthropology in order to draw a more complete picture of the role of households and their regulation in a globalized world of economic relations. In the United States, the academic and popular debate on the role of the family in the economy often proceeds from the assumption that much economic and social dysfunction could be corrected if broken family structures could be mended so as to perform the role that properly belongs to the family: fully internalizing costs of dependency. The Greek case study offers a counter-narrative in which families fully undertook to internalize that cost and, in the process, became part of much dysfunction in the market and the state.

The first part of the Article provides a theoretical framework for capturing the array of different legal regimes that may be important in determining household structure and function. The second part of the Article draws from this theoretical framework to analyze the role that households played in the economic development of Greece in the last thirty years. The third part draws some of the implications of household analysis for future developments in Greece and Europe more broadly.

\section{THEORIZING THE ECONOMIC HOUSEHOLD AND ITS REgULATION}

This section integrates theoretical analyses of the household in a variety of literatures in order to illuminate the role of households in the economy. First, I will define the concept of household that this Article is working with and then discuss different understandings of households in economics, political economy, and feminism. I argue that for all but the most structuralist perspectives, the legal regulation of the household is very important in defining the functions that households end up playing in a specific economy and the distribution of resources within households. Drawing from this analysis I discuss the array of legal regimes that one needs to understand in order to fully grasp the regulation of the household and how that might define the role of households in the economy.

\section{A. The economic household or "there and back again"}

Economists and feminist theorists in a variety of fields have long observed that households are an integral part of market economies. ${ }^{18}$ At a minimum, they provide the basic

\footnotetext{
${ }^{18}$ Even though Gary Becker is often said to be the first one to develop formal economic models on household production, he is by no means the first theorist to direct attention to household work as economically productive. As early as the nineteenth century, prominent feminist author and activist Charlotte Perkins Gilman extensively discussed the economic condition of housewives. According to Gilman, housework is economically valuable, even though it is unpaid and therefore places women in a state of absolute economic dependency on men. Gilman did not challenge the unpaid nature of women's work and treated instead women's market idleness as the problem calling for a solution. Charlotte Perkins Gilman, Women And ECONOMics: A Study of the ECONOMIC RELATION Between Men and Women AS A Factor In Social Evolution (Univ.of Cal. Press 1998) (1898). Within the field of economics, Margaret Reid's doctoral thesis, entitled Economics of Household Production, contained many of the basic ideas later formalized and expounded upon by Gary Becker, who was Reid's student at the University of Chicago. See Margaret G. Reid, Economics of Household Production (1934). See also Beyond Economic Man: Feminist TheORY And ECONOMics (Marianne A. Ferber \& Julie A. Nelson eds., 1993); Isabel V. Sawhill,
} 
"raw materials" for a working economy, namely the reproduction of labor and human capital. Additionally, they are important producers of goods and services, such as homemade meals and childcare, often performed without pay inside the household, but sometimes also produced for sale in the market. ${ }^{19}$ As part of an economy fuelled by mass consumption, households are also major actors as motors in a consumption-based model of economic growth. ${ }^{20}$ Finally, households are also major employers of domestic service providers. ${ }^{21}$ As feminists have often observed, these basic economic functions of the household can remain invisible because of identification of households with families, and of families, with the private, unproductive domain of altruistic behavior. $^{22}$

Within law, feminist scholars and critical theorists analyzed how the public/private distinction, which works as a basic underlying principle of many western legal regimes, rests on moveable ideological premises. ${ }^{23}$ The way the line between the public and the private is drawn distributes symbolic, legal and material resources. ${ }^{24}$ This distribution in the past has often disadvantaged women vis a vis men and children vis a vis parents. ${ }^{25}$ Comparative family law scholars have also tracked the genealogy of family law as a taxonomic category in law. ${ }^{26}$ They noted that the definition of the field obscures from our view the ongoing regulation of ongoing families and their distributional effects, arguing for a return to the household as the basis of analysis.

Economic Perspectives on the Family, 106 DaEdalus 115, 120 - 21 (1977); Marianne A. Ferber \& Bonnie G. Birnbaum, "The New Home Economics:" Retrospects and Prospects, 4 J. CONSUMER RES. 19 (1977); Ann Laquer Estin, Love and Obligation: Family Law and the Romance of Economics, 36 WM. \& MARY L. REV. 989 (1995); Barbara R. Bergman, The Economic EMERgence of Women 266-73 (1986). Sylvia Junko Yanagisako, Family and Household: the Analysis of Domestic Groups, AnNuAl REvIEw of ANTHROPOLOGY, 1979 at 161 - 205 ; Susan Donath, The Other Economy: A Suggestion for a Distinctively Feminist Economics, 6 FEMINIST ECONOMICS, no. 1, 2000 at 115 - 123; Cynthia A. Wood, The First World/Third Party Criterion: A Feminist Critique of Production Boundaries in Economics, 3 FEMINIST ECONOMICS, no. 3, 1997 at $47-68$.

${ }^{19}$ Becker posited that in addition to producing goods and services that could be sold in the market, households also produce unique household commodities, produced and consumed within the household ("children, prestige and esteem, health, altruism, envy, and pleasures of the senses") GARY S. BECKER, TREATISE ON THE FAMILY 24 (enlarged edition 1991).

${ }^{20}$ Duncan Standon Ironmonger, Household Production and the Household Economy, (University of Melbourne Department of Economics, Working Paper, 2000).

${ }^{21}$ Global Woman: NANNIES, MAIDS, AND SeX Workers In THE New Economy (Barbara Ehrenreich \& Arlie Russell Hochschild, eds., Macmillan, 2003).

${ }^{22}$ Frances Olsen, The Family and the Market: A Study of Ideology and Legal Reform, 96 HARV. L. REV. 1497 (1983); Katharine Silbaugh, Turning Labor into Love: Housework and the Law, 91 Nw. U. L. REV. 1 (1996); Katharine Silbaugh, Commodification and Women's Household Labor, 9 YALE J.L. \& FEMINISM 81 (1997).

${ }^{23}$ Frances Olsen, The Family and the Market: A Study of Ideology and Legal Reform, 96 HARV. L. REV. 1497 (1983); Duncan Kennedy, Stages of the Decline of the Public/Private Distinction, 130 U. PA. L. REV. 1349 (1981).

${ }^{24}$ Susan Moller Okin, Gender, the Public and the Private, in FEMINISM AND Politics 116 - 141 (1998).

${ }^{25}$ Frances Olsen, Constitutional Law: Feminist Critiques of the Public/Private Distinction, 10 CONST. COMMENT. 319 (1993); The Public Nature of Private Violence: The Discovery of Domestic Abuse (Martha Fineman \& Roxanne Mykitiuk, eds., Psychology Press, 1994); Robin West, Progressive Constitutionalism: RECONSTRUCTING THE FourTEENTH AMENDMENT 164, 165 (1994)

${ }^{26}$ Janet Halley \&Kerry Rittich, Critical Directions in Comparative Family Law: Genealogies and Contemporary Studies of Family Law Exceptionalism, 58 AM. J. CoMP. L. 753 (2010); Philomila Tsoukala, Marrying Family Law to the Nation, 58 AM. J. CoMP. L. 873, 873 - 910 (2010); Fernanda G. Nicola, Family Law Exceptionalism in Comparative Law, 58 AM. J. CoMP. L. 777 (2010); Yun-Ru Chen, Family Law As A Repository Of Volksgeist: The Germany-Japan Genealogy, 4 COMP. L. REV. 2 (2014). 
This Article aims to contribute to this comparative family law literature. For the purposes of this Article, I will use the term household to denote a group of people pooling resources in order to ensure the group's daily, as well as long-term reproduction. ${ }^{27}$ Even though the most common resource pooled is often a household dwelling, with members residing under one roof, this is not a necessary pre-condition for the purposes of this definition. Absentee students may be members of the parental household, despite lack of residence if the parents cover their expenses. On the other hand, familial relations or relations of kin are not a necessary precondition for membership in the household. A co-resident nanny belongs to the household, even though she may be legally counted as an employee. Finally, exclusive household membership is not a requirement either. The migrant nanny is a good example. She belongs to the household of destination because she is pooling resources, her labor, with other household members, who are pooling a residence with her, but she is also part of the household of origin, where she presumably sends a big part of her salary for the purposes of that household's survival, daily maintenance and long-term reproduction. So when we discuss households, we are not necessarily talking about families only, even though households can be identified with families under certain circumstances.

Political economists have analyzed the household as an integral part of the global capitalist economy. Global capital accumulation, according to these theorists, is based on hierarchical chains of production incorporating unequal exchanges making profit accumulation at the top possible. ${ }^{28}$ Households are at the basis of these long production chains, subsidizing capital accumulation through the invisibility and non-remunerated nature of their inputs into this chain. Feminist economists in the development literature have further analyzed how women's subsistence work subsidizes men's wages in the formal labor markets and profit accumulation at the top of chains of production. ${ }^{29}$

The starting point is the observation that wages paid by capital to buy labor historically has never been enough to ensure the reproduction of labor. ${ }^{30}$ Households, where the costs of human reproduction are typically internalized, have complemented market wages with various other types of income. ${ }^{31}$ The transformation from subsistence production to wage work was never complete and it is only the most privileged of working households that can afford to be entirely dependent on wages. Households located in peripheral chains of commodity production today (say the workers in the Philippino factory producing cheap textiles), will typically resort to

\footnotetext{
${ }^{27}$ The discussion of an appropriate definition of the household for the purposes of legal description deserves extensive treatment on its own. It is not, however, the object of this article. Here, I will follow as a preliminary issue the definition offered by Immanuel Wallerstein \& Joan Smith, Households as an Institution of the World-Economy, in CReating and TRAnsforming Households: The Constraints of the World ECONOMY (Immanuel Wallerstein \& Joan Smith eds., 1992). Even though Robert Ellickson's treatment of household regulation is betterknown within law, I am not following it here because it unnecessarily focuses on the real estate aspects of a household, excluding for example, an absentee student whose expenses are covered by her parents. See ROBERT C Ellickson, THE Household: INFORMal ORDER AROUND THE HEARTH (Princeton University Press, 2008). For another critique of Ellickson's definition of the household from within economics, see Shoshana Grossbard, Repack the Household: A Response to Robert Ellickson's Unpacking the Household, 116 Yale L.J.341 (2007).

${ }^{28}$ Immanuel Wallerstein \& Joan Smith, Households as an Institution of the World-Economy, in CREATING AND TRANSFORMING HOUSEHOLDS: THE CONSTRAINTS OF THE WORLD ECONOMY (Immanuel Wallerstein \& Joan Smith eds., 1992).

${ }^{29}$ ESTER BOSERUP, WOMAN'S ROLE IN ECONOMIC DEVELOPMENT (1970).

${ }^{30}$ Wallerstein \& Smith, supra note 28 , at 10.

${ }^{31} I d$. at $7-10$.
} 
small time market operations, like sales in the informal economy, along with all the subsistence income generated in the household through the unpaid labor of its members. Households located in core chains of commodity production (say the industrial workers of Germany's Siemens factories) are more dependent on wages for their survival, but they still need to make use of outside transfers coming from the state welfare regime in the form of housing, schooling, and other forms of subsidies. In addition, even households whose wages are above survival levels need to invest their free, non-commodified labor into productive work in the household, with the help of new technologies that may make this work less labor intensive but which do not fundamentally change the leisure time vs. working time equation.

The cyclicality of the global capitalist economy, with each phase of expansion and contraction puts certain types of pressure on households. ${ }^{32}$ In a contraction phase, as we are currently experiencing, there will be pressure to cut on costs, a burden which is easily placed on labor under conditions of global capital mobility. Households will experience even less capacity to survive on wages provided for labor in the market and they will in turn need to resort to complementary strategies, such as small-time market operations, and intensification of subsistence type activities within the household. Thus, downward pressure on wages may result in the restructuring of the household, as it expands to cope with a contractionary phase. ${ }^{33}$

Even though political economy provides useful insights in terms of the types of pressures households might receive based on different phases of the global economy, it assumes a unidirectional movement coming top-down from the global economy to households. However, households do not participate in the global economy only as producers of human capital and labor. They are also major units of consumption and in this sense, can experience different incentives based on how the global trade affects their consumption levels. ${ }^{34}$ The interests of households as sites of consumption might not necessarily align with their interests as producers of human capital. In addition, household members might choose to exert political pressure to perpetuate a regime that negatively affects their individual interests because of the intense redistribution of wealth that goes on within the family. Depending on context, households themselves might become important players in consolidating a specific regime of economic relations.

This effect seems to be aptly captured by Gary Becker's economic modeling of altruistic household behavior. Becker posited that even small amounts of redistribution within the household could lead selfish actors within the household to behave as if they were altruists, as if they had other-regarding preferences, if the income they could acquire within the household because of this redistribution exceeded income they could obtain in the marketplace. ${ }^{35}$ Hence, in the absence of resources outside of the household, a familistic regime strongly stacks incentives in favor of further intensification of redistribution within the family. Familism breeds more familism. Becker's micro economic model seems to have important macro economic implications.

Take for instance, a high unemployment, low-wage, low state welfare context such as has

\footnotetext{
${ }^{32}$ Id. at 17 .

${ }^{33} I d$.

${ }^{34}$ See, e.g., Mandana Arabi \& Edward Frongillo, Tortilla Price Changes and Household Consumption in Rural Mexico: Potential Effects of Free Trade Agreements, 20 FASEB Journal (2006).

${ }^{35}$ See Becker, supra note 19, at 285. For an explanation and critique of Becker's theories see Philomila Tsoukala, Gary Becker, Legal Feminism, and the Costs of Moralizing Care, 16 COLUM. J. GENDER \& L. 357 (2007)
} 
been prevalent in much of the European periphery. Chances for an income outside the household that would exceed the level of income achieved through household redistribution are reduced, hence incentives for trying to maximize household rather than individual income increased. ${ }^{36}$ The infamously familistic nature of welfare regimes in the European periphery has often been attributed to southern cultural norms. Becker's theory, however, implies that even a small amount of forced 'altruism' or redistribution within the family creates strong incentives for more redistribution and an intensification of alignment of individual interests with household interests. In the next section I will argue that this structural dynamic rather than entrenched cultural preferences is what better explains Greece's inability or unwillingness to proceed with market reforms considered necessary as early as its first accession to the EEC.

Households have more recently drawn the attention of development and global financial institutions operating within a neoclassical economic theory. ${ }^{37}$ In that context, households emerge as important sites for regulatory reforms especially to the extent that they might impede women's increased participation in labor markets. Ultimately, the reforms envisaged by development institutions aim at liberating individuals from the shackles of the household, so that those individuals might become integrated in a market economy. Households are assumed to be appropriately internalizing the costs of dependency with the state responsible only for a series of human capital measures, such as training programs and activation measures, in order to induce 'inactive' people to enter formal labor markets. ${ }^{38}$ An ideal family/market line drawing is therefore assumed by many of these projects.

Economic theory has also offered important insights on the economics of the family from a micro structural perspective. Becker's attempts to model behavior within the household on the basis of the assumption of a single household function were largely replaced by bargaining models of the family, which do not stray from the basic assumption about individuals maximizing their own utility functions. ${ }^{39}$ Bargaining theory has been mostly concerned with bargaining within marriages and with the conditions that affect each spouse's bargaining strength. One of the insights from this literature for the purposes of law has been the idea that legal entitlements at divorce are likely to influence that bargaining power of spouses within an ongoing marriage and not simply at the moment of exit. "Bargaining in the shadow of the law" in other words is not simply an issue of importance for dissolving marriages but likely defines the types of incentives married partners face while the marriage is still ongoing. ${ }^{40}$

\footnotetext{
${ }^{36} I d$.

${ }^{37}$ Kerry Rittich, Black Sites: Locating the Family and Family Law in Development, 58 AM. J. COMP. L., no. 4 , 2010 at $1023-1054$.

${ }^{38}$ Id. Kerry Rittich identifies three emerging areas of reform: protection from gender inequality in the household and the market that might diminish women's labor participation, investment in women as a fast-track to social protection without the assumed downsides of creating a welfare regime, and formalization of labor markets with the assumption that informality itself is impeding women from entering the market as workers. Id.

${ }^{39}$ For an overview of the economic literature that tries to break up Becker's 'unitary' model of the family and instead inquire into the ways decisions within multi-person households are being made and resources distributed, see M. Browning \& P.A. Chiappori, Efficient Intra-Household Allocations: A General Characterization and Empirical Tests, 66 ECONOMETRICA, no. 6, 1998 at 1241 - 1278. For a more accessible explication of the models that have been developed in economics, see Robert A. Pollak, Bargaining Power in Marriage: Earnings, Wage Rates and Household Production (Nat'l Bureau of Econ. Research, Working Paper No. 11239, Mar. 2005), available at http://www.nber.org/papers/w11239.

${ }^{40}$ Robert H. Mnookin \& Lewis Kornhauser, Bargaining in the Shadow of the Law: The Case of Divorce, 88 YALE L.J. 950 (1979).
} 
Household, rather than marital, bargaining has been theorized most extensively by Bob Ellickson, who posited that household members do not in fact bargain in the shadow of the law but instead come up with heir own informal norms through repeated interactions that are geared towards maximizing efficiency. ${ }^{41}$ Even under Ellikson's framework, however, the legal framework surrounding the household remains important especially when we are talking about households that contain highly legalized relations such as married partners, or landlords and tenants.

\section{B. Households and their law}

With an understanding of the economic role of households, we are in a position to examine how the law might influence and structure that role. The precise nature of how households are integrated in the broader economy will partly depend on: 1) the legal regimes affecting the distribution of resources between household members, and 2) the legal regimes that define the role of the household in relationship to the market and the state, as well as those regimes that define background fiscal conditions. One could name the first question, concerning the distribution of resources between household members, the micro structural perspective. The second question, the relationship between the household, the state, and the market, could be called the macro structural perspective.

In order to be able to understand household dynamics from a micro structural perspective one would need to have a very good grasp of a host of different legal regimes affecting the bargaining endowments of different household members as they negotiate the distribution of household "surplus. ${ }^{42}$ If we are talking about households containing married couples, for example, we would need a good understanding of the family law rules that affect the exit options and fallback positions for each spouse. ${ }^{43} \mathrm{We}$ would also need to have a good grasp of a host of other legal regimes affecting ongoing married coupledom, such as social security, welfare law, insurance, healthcare, and taxation, to name some key ones. ${ }^{44}$ Finally, to the extent that there is a tradeoff involved between hours spent working in the market and hours spent working in the household, one would also need to understand the basic market conditions that shape the fallback positions of household members in charge of care work.

Importantly, those legally determined market conditions would influence the opportunity cost for each member of the household. If the opportunity costs for working in the market were determined for each member of the household in ways predictably consistent along lines of gender, for example, then repeated micro interactions between household members 'in the shadow of the law' could produce observable macro results such as specific effects of rules on women's market participation. These results in turn would influence the balance between the household, the market and the state in the provision of care. ${ }^{45}$ As Becker's theory of the sexual

\footnotetext{
${ }^{41}$ See Ellickson, supra note 27.

${ }^{42} I d$.

${ }^{43}$ Amy L. Wax, Bargaining in the Shadow of the Market: Is there a Future for Egalitarian Marriage?, 84 VA. L.R. 509 (1998).

${ }^{44}$ Halley \& Rittich, supra note 26.

${ }^{45}$ Becker argued that women have a comparative advantage in household work coming from their role in sexual reproduction. SeeBecker, supra note 19. For a critique showing that Becker is not really demonstrating that the
} 
division of labor suggests, as long as there is even a small wage gap between men and women in the market, there will always be efficiency gains from specialization and trade, which in turn means, that there will be a continued tendency to divide household work along lines of gender. ${ }^{46}$ Similarly, a regime that at divorce fully compensated spouses for the marriage-specific investments they made would enable making those marriage specific investments and could further intensify specialization of labor between the household and the market rather than encouraging equal division of household and market roles. ${ }^{47}$

We could start with the background fiscal framework that determines how much of those costs can be internalized by the state via taxation and/or borrowing. Fiscal austerity, such as the one currently imposed through the EU's new macro-economic governance framework, ${ }^{48}$ means that states are internalizing less of those costs because they are cutting back on expenditures they consider redundant. ${ }^{49}$ That often means cutting expenditures of the welfare state, which is the regime through which states assume some of the maintenance/reproduction costs of the workforce. In the past, rolling back welfare benefits has translated into more caretaking obligations for households, which in turn translates into less market participation by women. ${ }^{50}$

Even assuming a regulatory regime of fiscal expansion however, it is not at all certain that those costs are going to be internalized by the state. That depends on the type of welfare regime in place. Esping Andersen's widely used typology of welfare regimes can help us clarify the degree to which households are spared some of the costs of reproduction and daily maintenance. ${ }^{51} \mathrm{He}$ identified three distinct ideal types of welfarism, naming them the universalist (like Sweden), the corporatist (like Germany), and the liberal (like the US), measuring different degrees of de-commodification and defamilialization. ${ }^{52}$ His de-commodification index tells us whether a state allows individuals any degree of freedom from the need to sell their labor in the market, by providing subsidies through transfers. ${ }^{53}$ The higher the de-commodification index the

advantage comes from the women's role in reproduction, but rather from heavy investment in 'household' human capital, see Philomila Tsoukala, Gary Becker, Legal Feminism, and the Costs of Moralizing Care, supra note 35.

${ }^{46}$ Even if we were to take another of Becker's unpopular theories, that of the sexual division of labor, we could see that there are important theoretical points of significance for any legal scholar interested in the regulation of the household. Becker transposed general comparative advantage theory to the family by positing the sexual division of labor could be in fact attributed not to female oppression but to efficiency gains from specialization and trade. In the process, he employed a reductionist version of female human capital as by nature comparatively more efficient at household rather than market labor. But the main insight does not depend on this assumption. Becker's theory of comparative advantage in the household suggests that even a small disadvantage of women in the marketplace, say because of the wage gap, could lead couples to choose to specialize and trade rather than equally split their time between household and market. Becker, supra note 19.

${ }^{47}$ Beyond marriage based household relations, a host of other regimes at the basis of or serving as the background to household relations would also need to be analyzed for different types of households; such as landlord-tenant, property law, various types of torts, mortgage and credit regulation, bankruptcy, taxation, housing and zoning law, any law regulating domestic work and immigration law affecting household members who are employed as domestic workers.

${ }^{48}$ Philomila Tsoukala, Euro Crisis Management and the New Social Europe, 20 CoLUM. J. EUR. L. 31,31 - 76 (2013).

${ }^{49}$ Women And Austerity: The ECONOMIC CRISIS AND THE Future FOR Gender EQUALITY (Maria Maramessini \& Jill Rubery eds., 2013).

${ }^{50}$ KERRY RitTICH, RECHARACTERIZING RESTRUCTURING: LAW, DisTRIBUTION AND GENDER IN MARKET REFORM (2002)

${ }^{51}$ See Gøsta Esping-Andersen, The THree Worlds of Welfare CAPITAlism (1990).

${ }^{52} \mathrm{Id}$.

${ }^{53} I d$. 
more a state is taking on some of the costs of maintenance/reproduction as opposed to the household. His de-familialization index measures whether a welfare regime allows individuals to be freed from personal obligations of caretaking. ${ }^{54}$ Defamilialization does not mean that the household is freed from all of the costs of providing care. It may still need to assume them by buying services in the market. ${ }^{55}$

According to Esping Andersen's ideal type of welfare regimes then, states assume more of the costs of care vis a vis the household in universalist regimes as compared to any other ideal type. Following is the continental/corporatist type, and last is the liberal welfare regime where most of the costs of maintenance/reproduction are internalized by the household. Other scholars have referred to a fourth ideal type of welfarism, which is characterized by low degrees of decommodification and high levels of familialization. Countries like Greece, Italy, and Portugal have been said to belong to a "Mediterranean" style welfare regime. ${ }^{56}$

The overall structure and characteristics of markets can also tell us a lot about how households are regulated. Labor markets, and more specifically, the opportunities for women within them, can tell us a lot about women's opportunity costs, which in turn affect birth rates and women's participation rates in the labor market. ${ }^{57}$ Women's labor market opportunities will also depend on the levels of protection provided against gender discrimination, but also, the availability of state or market alternatives to personally provided care work. In liberal welfare regimes, where the state does not provide subsidization for care work, women have been able to increase their labor market participation rates through the widespread use of cheap migrant labor. ${ }^{58}$ Hence, the immigration regime that partly determines the wage that a nanny can command will also need to be analyzed in order to get a full sense of household regulation.

As far as household structure is concerned, Wallerstein and Smith suggest that households that coincide with nuclear family structures have only been possible where the costs for reproduction and maintenance have been partly internalized by markets (capital rather than labor) or the state, rather than directly by households themselves. In the US, journalists noticed the "back to the nest" move by many unemployed college educated adults after the 2008 crisis, wondering about the potential duration of the phenomenon. ${ }^{59}$ In Europe, between 2001-2008, the credit bubble produced by overfinancialization and the euro, fuelled an "out of the nest" phenomenon for countries whose high rates of adult, multigenerational co-residence had often been attributed to culture. ${ }^{60}$

\footnotetext{
${ }^{54} I d$.

${ }^{55}$ See Hila Shamir, The State of Care: Rethinking the Distributive Effects of Familial Care Policies in Liberal Welfare States, 58 AM. J. COMP. L. 953, 953 - 986 (2010).

${ }^{56}$ Wil Arts and John Gelissen, Three Worlds of Welfare Capitalism or More? A State-of-the-Art Report, 12 J. EUR. SOC. POL'y 137, 137 - 158 (2002).

${ }^{57}$ Becker, supra note 19.

${ }^{58}$ See, e.g., Peck-Leong Tan \& John Gibson, Impact of Foreign Maids on Female Labor Force Participation in Malaysia, 27 ASIAN ECON. J., no. 2, 2013 at 163-183.

${ }^{59}$ The number of 26 year olds living with their parents has jumped $46 \%$ since 2007 according to US census data. See Kathy Warbelow \& Frank Bass, Young U.S. Adults Flock to Parents' Homes Amid Economy, BLOOMBERG NEws, Sept. 25, 2012, http://www.bloomberg.com/news/2012-09-25/young-adults-flock-to-parents-homes-amid-soureconomy.html.

${ }^{60}$ Bettina Isengard \& Marc Szydlik, Living Apart (or) Together? Coresidence of Elderly Parents and their Adult Children in Europe, 34 RESEARCH ON AGING 449, 449 - 474 (2012); For an account of how labor markets and mortgage markets, but also gender, affect age of leaving the parental home around Europe, see Maria Concetta
} 
Getting a sense of background market conditions, such as degree of liberalization of services and goods, degree of protection from gender discrimination in the market is central to the project of figuring out how households are regulated. In other words, the basic institutional setup of market regulation is an important background condition, potentially influencing household structures and functions. Thus, understanding household dynamics within the global economy also entails understanding the way a set of interlocking legal regimes structure incentives for individual household members and divide responsibilities for basic welfare provision between the family, the market, and the state.

The next part of the paper uses this framework to explore the hypothesis that the basic political dynamics of stasis in the face of reforms long required of Greece in the context of its membership in the European Union can be explained by the pressures exerted by households organized as families and by the survival strategies they adopted in the face of an unstable economic environment. The combination of a background regime of European market integration, combined with a patchy -at best- welfare provision by the Greek state, created incentives for the intensification of redistribution within the Greek family. A host of legal and regulatory incentives were put in place that reinforced this dynamic and the Greek family became one of the main vehicles for the distribution of wealth within Greek society. By the time Greece entered the European Economic Community (EEC later to transform into the EU) in 1981, the Greek household, organized mostly as family, was already one of the main modes of providing basic welfare and was ubiquitous in the economy. By the beginning of the nineties, rational actors would be able to recognize that the most promising game in town would be trying to maximize family rather than individual utility.

\section{HOUSEHOLD REgULATION AND EUROPEAN INTEGRATION: THE GREEK CASE}

In this section, I describe the Greek economic and regulatory background before its accession to the EEC and then discuss how the European market integration further consolidated the Greek family's stronghold on economic, political, and social relations. Before that, however, I revisit some of the most commonly invoked ideas about the country's economic woes.

\section{A. Captured State, Ottoman Citizens and A Puzzle}

The troika of Greece's lenders attributed Greece's woes to unsustainable growth drivers coupled with persistent overspending and tax evasion. ${ }^{61}$ The loan conditionality focused heavily on fiscal austerity, and structural reforms in the public sector and the labor markets. ${ }^{62}$ It warned that implementing reforms would require overcoming resistance from "lobbies and vested interests" and "break[ing] longstanding policy taboos." "63 In its first review of the program, the

Chiuri \& Daniela Del Boca, Home-Leaving Decisions of Daughters and Sons, 8 REv. ECON. OF THE HousEHOLD 393, 393 - 408 (2010).

${ }^{61}$ European Comm'n, The Economic Adjustment Programme for Greece, May 2010,3, http://ec.europa.eu/economy_finance/publications/occasional_paper/2010/pdf/ocp61_en.pdf [hereinafter EAPGR1].

${ }^{62}$ See EAPGR1, supra note 61; EAPGr2, supra note 10.

63 EAPGR2, supra note 10 , at 4 
troika attributed delays in structural reform implementation to "vested interests" and the "prevailing rent-seeking mentality of powerful pressure groups." ${ }^{64}$ The troika also focused on alleged "downward rigidities" for wages in the labor markets, which in its view impeded a quick adjustment of the Greek economy, but which also unfairly impacted the employment prospects of 'outsider' worker groups such as youth and women. ${ }^{65}$

The story of vested interests defending Greek state inefficiencies was not a new one. Academics since the early nineties had noticed that the Greek state was massively inefficient and seemed to cater to the interests of certain social groups over others (namely public sector over private sector workers, men over women, the old over the young, the liberal professions over the salaried). ${ }^{66}$ Greek labor markets had been characterized as dual, with a group of insiders, namely unionized employees and the liberal professions, enjoying privileges to the detriment of the outsiders and the overall efficiency of the Greek economy. The relevant literature had repeatedly attributed reform failures to vested interests reacting and dynamiting every possible effort in this direction. $^{67}$

At the same time, another powerful narrative emerged. A prominent Greek academic, who later became the European Ombudsman, Nikiforos Diamantouros, famously offered a cultural explanation to Greek reform failures. ${ }^{68}$ Diamantouros claimed that an underdog culture having its roots in the Ottoman years was always in competition with a modernizing, westernizing attitude and always found itself in the majority, with the westernizers slowly gaining ground only after accession to the EU. Diamantouros's assessment was that it was the cultural attitude that impeded rationalizing reforms in all domains, including labor markets. ${ }^{69}$ Echoes of the cultural explanations of Greek inefficiencies were repeated in the analysis of the 2009 crisis. In the academic press, scholars discussed the "culture of informality" and the "culture of tax evasion", calculating their costs to the tune of billions. ${ }^{70}$ In the political realm, politicians in creditor countries repeatedly suggested that the Greek state's problems were due to a culture lacking in work ethic, with corrupt politicians showering undeserving workers with excessive benefits. ${ }^{71}$

Neither one of these accounts can provide a sufficient explanation for how the Greek state came to be characterized by widespread waste and inefficiency. The explanation focusing on vested interests in the form of labor unions in the public sector fail to explain why repeated rounds of elections resulted in governments that would yield to the demands of such vested

64 European Comm'n, The Second Economic Adjustment Programme for Greece First Review, Dec. 2012, 5, http://ec.europa.eu/economy_finance/publications/occasional_paper/2012/pdf/ocp123_en.pdf. (“A return to sustained growth can only be achieved when the structural reform agenda is fully and swiftly implemented. This will require breaking the resistance of vested interests and the prevailing rent-seeking mentality of powerful pressure groups.") $I d$.

${ }^{6}$ EAPGR2, supra note 10, at 9.

${ }^{66}$ See, e.g., Louka T. Katseli, Structural Adjustment of the Greek Economy, (CEPR Discussion Papers, No. 374, 1990).

${ }^{67} \mathrm{Id}$.

${ }^{68}$ Nikiforos P. Diamantouros, Cultural Dualism and Political Change in Postauthoritarian Greece, (Estudios/Working Papers, Centro de Estudios Avanzados en Ciencias Sociales 1994).

${ }^{69}$ Id.

${ }^{70}$ Nikolaos Artavanis et al., Tax Evasion Across Industries: Soft Credit Evidence from Greece, (Chicago Booth Research Paper, Working Paper No. 12-25, (2012).

${ }^{71}$ For an analysis of these narratives and their fallacies, see Philomila Tsoukala, Narratives of the European Crisis and the Future of (Social) Europe, 48 TEX. INT'L. L.J. 241, 241 - 267 (2013). 
interests. If the Greek labor market was simply organized on the basis of the individual interests of individual workers, public sector unions would have long been dismantled or effectively resisted by governments elected with a clear mandate from private sector employees seeking to demolish public sector privileges. In addition, public sector employees should theoretically share an interest with private sector workers in ending the liberal professions' tax evasion, which predictably hurt the working class' savings and access to public services.

The cultural explanation, which relies on political "orientalism" embedded in mindless repetition of learned practices, is even more deficient. Cultures are not immutable black boxes. The influence of Europe since Greece's accession, a process that started as early as 1961, should have made an important dent on any alleged cultural tendency towards inefficiency and corruption. Even Diamantouros, one of the main propagators of the cultural argument, predicted that accession to the EU would eventually reinforce the "westernizing" strand in Greek culture and lead to the acceptance of dramatic reforms in the basic structures of the Greek state. Why did his prediction fail?

Finally, an explanation that puts forward the traditional clientelism of the Greek electoral system seems somewhat tautological. Clientelism merely describes the behavior through which politicians buy voters in exchange for personal benefit, usually an appointment in the public sector job. But the concept itself does not provide an explanation for the dynamic that brought about its birth. Why wouldn't the vast majority of Greeks vote to eradicate such practices? After all, the distribution of state jobs along party lines should have meant that because of the predominance of two parties at most moments in recent history, a strong minority or even a small majority stood to lose from the cooptation of state benefits by the party in power.

Public choice theory has shown that a strong minority can in fact impose its agenda on a diffuse majority. However, the claim of this article is that most people in Greece at most times, while individually members of a majority, whose individual interests would have been better served by dismantling corruption and tax evasion, were at the same time, indirectly, through family relations, part of the 'strong minority', because they could rationally expect to profit from the continuation of the status quo through family relations. In other words, the failure of political support for effective reforms against tax evasion and corruption, may have in fact become consolidated not through a process of minority strong-arming the majority, but because a majority of individuals were engaged in the process of maximizing their family rather than their individual utility.

\section{B. Pre-accession economic and regulatory background}

The economic history of Greece is characterized by a post WWII boom period. ${ }^{72}$ The

\footnotetext{
${ }^{72}$ Greece emerged from WWII with major economic losses. The economy was reconstructed with help from the U.S. funded Marshall plan. See Apostolos Vetsopoulos, Efforts for the Development and Stabilization of the Economy during the Period of the Marshall Plan, 27 J. MODERn GREEK STUDIES, no. 2, Oct. 2009. The stabilization efforts for Greece were part of a western plan to stop communist influence and keep the country outside of the Iron Curtain. See John Iatrides, George F. Keenan and the Birth of Containment: The Greek Test Case, 22 WORLD POL'Y J. 126 (2005). Starting in the mid-fifties and until the early seventies oil crisis, Greece grew rapidly with rates of growth "comparable to that of high achievers such as postwar Japan." See GEORGE PAGOULATOS, GREECE's NEW Political ECONOMY: STATE, FinANCE AND GROWTH FROM POSTWAR TO EMU 5 (2003).
} 
"Greek miracle" of the period between 1950s-1970s was based on low inflation, low wages and intense political repression. ${ }^{73}$ The government controlled labor unions and controlled the losers of the (1946-1949) civil war through direct and indirect ways of exclusion. ${ }^{74}$ Political repression intensified leading to a dictatorship in $1967 .{ }^{75}$ The shock to the Greek economy from the oil crisis arguably provided some of the ground for political contestation, which eventually led to the ousting of the dictatorship in $1974 .{ }^{76}$ Greece's economy had started slowing since the early 1970s, dipping into a sluggish $1.5 \%$ GDP annually after its 1981 accession to the EEC and until $1995 .^{77}$

Greece's economy underwent significant transformations in the postwar era. Until about the 1960s, Greece's main economic activity was agriculture. In 1961, Greek agriculture provided $53.4 \%$ of employment in the economy, contributing $21.3 \%$ of Gross Value Added (GVA). ${ }^{78}$ By 1981 the Greek agricultural sector had shrunk, providing $27.4 \%$ of employment and $14.6 \%$ of GVA. ${ }^{79}$ The correlative change was some growth in industry, which included shipping, mining, and small-scale manufacturing especially in textiles and an exponential growth in the services sector, which was mainly domestically oriented. The manufacturing sector's growth was partly due to Greece's prior-somewhat haphazard policy- of import substitution and 'infant industry' protection $^{80}$. It was partly due to the relocation strategies of central European manufacturers, especially from Germany, moving some of their production to Greece because of its lower labor costs and the benefits of its association agreement with the EEC in place since $1961 .^{81}$

At this point, Greece did not have a welfare state, of the universal, the corporatist or the liberal type. ${ }^{82}$ Greeks relied on their families for provision of basic welfare. ${ }^{83}$ They also relied on

\footnotetext{
${ }^{73}$ See George Pagoulatos, Greece's New Political Economy: State, Finance and Growth From Postwar TO EMU 35 - 45 (2003).

${ }^{74}$ Nikos Mouzelis, Modern Greece: Facets of Underdevelopment (1978); Mark Mazower, After the WAR WAS Over: Reconstructing the FAMily, NATiOn, AND State IN GreECE, 1943-1960 (2000). On the persecution of the left, see NENI PANOURGIA, DANGEROUS CITIZENS: THE GREEK LEFT AND THE TERROR OF THE STATE (2009). On the gendered nature of political persecution in post WWII Greece, see KATHERINE STEFATOS, ENGENDERING THE NATION:WOMEN, STATE OPPRESSION AND POLITICAL VIOLENCE IN POST-WAR GREECE (19461974) (2011) (Ph.D. thesis, London School of Economics), available at http://www.1se.ac.uk/europeanInstitute/research/LSEE/PDFs/PhD\%20Symposium/Papers\%202010/Stefatos.pdf.

75 Richard Clogg \& GeORge N. YANnOPOUlos, GreECE Under MilitARY Rule (1972); Nicos Mouzelis, On the Rise of Postwar Military Dictatorships: Argentina, Chile, Greece, 28 COMP. STUDIES IN SOC'Y \& HISTORY, 1986 at $55-80$.

${ }^{76}$ George Alogoskoufis, Francesco Giavazzi, \& Guy Laroque, The Two Faces of Janus: Institutions, Policy Regimes and Macroeconomic Performance in Greece, 10 ECON. POL'Y, no. 20, 1995 at 155. The oil crisis caused the Greek government to go from consistent general budget surpluses of about one percent in the 1960s to increasing deficits in the 70s, averaging 9\% in the 80s and reaching 16\% GDP in the 90s. See Barry Bosworth \& Tryphon Kollintzas, Economic Growth in Greece: Past Performance and Future Prospects 15 (CEPR Discussion Paper, No. 2852, 2001).

${ }^{77}$ See Bosworth \& Kollintzas, supra note 76. The sluggish rate of growth continued until 1995, when Greece entered a new phase of strong growth, which was, however fuelled by the credit bubble. Id.

${ }^{78}$ George C. Bitros, From Riches to Rags or What Went Wrong in Greece, 38 J. ECON. \& Soc. MEASUREMENT 5,5 39 (2013).

${ }^{79} \mathrm{Id}$.

${ }^{80}$ See Pagoulatos, supra note 72.

${ }^{81}$ Lois Labrianidis \& Christos Kalantaridis, Globalization and Local Industrial Development in the European Periphery: Enterprise Strategies in Eastern Macedonia and Thrace, 5 EUR. PlAn. STUD. 477, 477 - 494 (1997).

${ }^{82}$ This is partly because Greece's turbulent political past impeded social consensus for the creation of universal benefits. George S Katrougalos, The South European Welfare Model: the Greek Welfare State, in Search of an
} 
their families for the provision of employment. The main pillar of the Greek private sector after World War II was the small, or even micro, family business. In his in-depth analysis of Greece's political economy in the postwar era George Pagoulatos discusses how "an archipelago of small, family-based enterprises...absorbed a considerable proportion of the unemployed and underemployed." 84 Despite the inefficiencies generated by the fragmentation of the Greek business scene politicians continued to sustain it, by tolerating widespread informality, the exploitation of the unpaid labor of family members, and widespread tax evasion. ${ }^{85}$

Successive governments refused to withdraw targeted credit policies towards the small family-based business because of the political payoff in getting the support of vast swaths of micro-business owners and their family members. The result was the survival of these businesses as "the backbone" of the Greek political regime and the backbone of the Greek middle class" survival. One of the other tools used by the Greek state to diffuse economic demands by the lower and middle strata was state employment. State-administered finance in the context of import substitution, along with the clientelist provisioning of state jobs and unwavering support to small businesses through widespread tolerance of informality created a de facto substitute for a European-style welfare state. ${ }^{86}$

The Greek household then was central in the provisioning of basic welfare to its members, either directly, through subsistence work in an agricultural setting, or indirectly, through informal employment in the context of the small family business. The provisioning of state employment on political party clientelist basis still relied heavily on underlying family networks. The civil war had left the Greek social scene divided into right and left wing families, belonging to parties affiliated with the right or the left. Greek households then could easily be identified with one or the other side and were important mediating mechanisms for the distribution of and exclusion from state controlled resources.

Greek family law provided a legal framework that was consistent with the family's function as an economic unit and the husband's role as the head of the unit. ${ }^{87}$ The Family Law chapter of the Greek civil code enshrined a system of formally unequal gender relations. From the perspective of property, the code adopted a separate properties regime, with an important amendment: the husband acquired a life-estate on property brought into the marriage as dowry by the wife. In exchange, the wife had the right to be supported by the husband and the husband had a duty to manage and account for the property brought in as dowry. The most common scenario was that families would use capital from the wife's dowry to kick-start a small family

Identity, 6 J. EuR. Soc. PoL'y 39, 39 - 60 (1996); Maria Petmesidou, Social Protection in Greece: a Brief Glimpse of a Welfare State, 30 SoC. POL'Y \& ADMIN. 324 (1996). Manos Matsaganis, The Welfare State and the Crisis: the Case of Greece, 21 J. EUR. SOC. POL'Y 501, 501 - 512 (2011); Manos Matsaganis et al., Mending Nets in the South: Anti-Poverty Policies in Greece, Italy, Portugal and Spain, 37 Soc. POL'y \& AdMIN. 639, 639 - 655 (2003).

${ }^{83}$ Theodoros N. Papadopoulos, Greek Family Policy from a Comparative Perspective in WOMEN, WORK AND THE FAMILY IN EUROPE 47 - 57 (London: Routledge, 1998).

${ }^{84}$ Pagoulatos, supra note 72 , at 36.

${ }^{85}$ Id. at 68

${ }^{86} \mathrm{Id}$. at 47.

${ }^{87}$ Aspasia Tsaoussi, The Greek Divorce Law Reform of 1983 and Its Impact on Homemakers: A Social and Economic Analysis (August 2000) (J.D. dissertation, University of Chicago). Philomila Tsoukala, The Greek Family Law Reform of 1983 : an Ex-Post Reconstruction of the Reform and an Inquiry into its Effects (2002) (unpublished LL.M. thesis, Harvard Law School) (on file with author). 
business that would sustain the family's members. ${ }^{88} \mathrm{~A}$ strict, fault-based divorce scheme disincentivized easy exit from marriages and consolidated the family as the basic unit for the taking care of dependents. Children and parents had reciprocal duties of care and support into adulthood.

Thus, when Greece entered the EEC in 1981, the Greek household was already consolidated as one of the main motors in the Greek economy, supported by a host of legal and regulatory incentives.

\section{Post-accession regulatory background and its effect on households}

One of the main goals of the European Union was to develop an internal market where factors of production, such as capital and labor move freely. Its theoretical basis can be found in neo-classical economic theory, which predicts welfare gains from specialization and trade. The legal institutional basis of the European internal market project can be found in the abolition of tariffs, the free movement provisions (goods, people, capital and services), along with competition law and the prohibition of subsidies.

Specialization and trade seems to be indeed what happened with European integration. Starting already from the EEC, as a precursor to the internal market, there was an overall move of European production away from agriculture and manufacturing and towards the service sector. ${ }^{89}$ As economists noted, however, the patterns of regional integration developed along a core/periphery model, with higher value manufacturing and services located in countries in the European core and lesser value ones located in the European periphery. ${ }^{90}$ Despite expectations that increased integration would gradually lead to a leveling of standards of living throughout Europe, the EU, starting in the $80 \mathrm{~s}$, became stuck in an equilibrium of big gaps between high and low unemployment regions, as well as persistent gaps in GDP per capita between different regions in the EU, even though national GDPs seemed to be converging. ${ }^{91}$

\footnotetext{
${ }^{88}$ Ioanna Minoglou, Women and Family Capitalism in Greece, c. 1780-1940, 81 Bus. HIST. Rev. 517, 517 - 538 (2007); Vasiliki Galani-Moutafi, From Agriculture to Tourism: Property, Labor, Gender, and Kinship in a Greek Island Village (Part Two), 12 J. MODERN GREEK STUD. 113 (1994).

${ }^{89}$ The move away from agriculture was a pan-European goal of the Common Agricultural Policy (CAP). See Robert ACKRILl, COMMON Agricultural POLICY (2000).

${ }^{90}$ Marius Brülhart \& Johan Torstensson, Regional integration, scale economies and industry location in the European Union (CEPR Discussion Paper Series, No. 1435, July 1996); Constantina Kottaridi, The 'CorePeriphery' Pattern of FDI-led Growth and Production Structure in the EU, 37 APPLIED ECON. 99 (2005); Martin Hallet, Regional Specialisation and Concentration in the EU, ECONOMIC PAPERS COMMISSION OF THE EUROPEAN Communities, Mar. 2000; Diego Puga, European Regional Policies in Light of Recent Location Theories (CEPR Discussion Paper Series, No. 2767, April 2001) ("Despite large regional policy expenditures, regional inequalities in Europe have not narrowed substantially over the last two decades, and by some measures have even widened. Income differences across States have fallen, but inequalities between regions within each State have risen. European States have developed increasingly different production structures. And European regions have also become increasingly polarised in terms of their unemployment rates."). But see John Bachtler \& Grzegorz Gorzelak, Reforming EU Cohesion Policy: A Reappraisal of the Performance of the Structural Funds, 28 POL'Y STUD. 309, 309 - 326 (2007) (arguing that structural funds have positively contributed to GDP per capita convergence, while acknowledging the regional disparity persistence).

${ }^{91}$ Diego Puga, European Regional Policies in Light of Recent Location theories (CEPR Discussion Paper Series, No. 2767, April 2001).
} 
EU Regional Policy specifically targeted some of the disparities, transferring money from the EU Budget to regions with GDP per capital less than $75 \%$ of the EU average. Much of this money was spent on large infrastructure projects aimed at easing transportation costs between different regions of the EU with the assumption that such a development would necessarily lead to freer movement of productive factors and therefore eventual economic convergence. ${ }^{92}$ However, ease of transportation may merely make market access for goods easier from core to periphery countries, making convergence harder rather than easier. ${ }^{93}$ In addition, many of these large-scale projects in the periphery may have resulted in a temporary ease of unemployment in the regions concerned and more GDP convergence at the national level- since the money transfer counts regardless of whether it ends up in private or public pockets- but they made no permanent dent on unemployment rates or regional divergence in GDP per capita. Moreover, it is arguable that the Structural Funds transfers made no real difference in the accumulation of human capital in the periphery. They certainly did not change anything in the allocation of productive activities, since their goal was never an investment in the productive capacities of a member state with the goal of moving it up in the global value chain of production.

The move away from agriculture and towards the service sector all around Europe means an overall tendency for households to be more dependent on wages for their survival than they were before. Households located in the European core would become relatively more dependent on wages than households located in the periphery, and higher concentration of agricultural households along with higher unemployment rates would translate into less wage dependency. High unemployment rates throughout Europe, however, would translate into uniform pressures on households everywhere to complement their income through subsistence work, market sales, or transfers-private or public. ${ }^{94}$ Which of these avenues for complementing income would be taken would in turn partly depend on the underlying regulatory structures that define regimes of public transfers, private transfers and basic market relations, such as the type of welfare regime in place, and basic market rules on property and contract, as well as tax regulation.

The countries that ended up in the economic periphery also tended to be countries falling under the Mediterranean model of welfare provisioning. Thus, the pressure on households coming from increased unemployment could not be counteracted by public transfers through the welfare state since the latter placed the main burden for dependency on families to begin with. The remaining options for complementing household income would have been private transfers, and other types of market operations such as sales and rental income. Widespread gender discrimination in the marketplace and the lack of cheap childcare options (public or private) would mean that sending more of the 'inactive' members, namely women, to the market for wages in response to the pressures on income coming from peripheralization would have been a strategy unlikely to succeed. The increase in female labor participation rates in the European periphery during the 70 s and 80 s were indeed much lower than the ones observed in liberal welfare regimes or corporatist and universalist regimes. ${ }^{95}$

The alternative option to alleviating the family from some of the dependency work burden in order to gain access to more wages would be intensifying market transactions such as

\footnotetext{
${ }^{92} I d$.

${ }^{93} \mathrm{Id}$.

${ }^{94}$ See discussion supra Section IA.

${ }^{95}$ Mary Daly, A Fine Balance: Women's Labor Market Participation in International Comparison, in WELFARE AND WORK IN THE OPEN ECONOMY, V II (F.Scharpf \& V. Schmidt eds., 2000).
} 
sales or rent. In southern European member states, where barriers to business entry relating to bureaucracy and limited credit availability were present at the time of accession, households would be likely to resort to informal market transactions as a subsistence valve. We would therefore expect to see an uptick in the informal sector as well as in tax evasion. The high prevalence of family businesses operating in the grey zone between formality and informality in the European periphery is a picture congruent with the types of pressures households would have been experiencing as a result of the basic institutional setup of the European integration project and its effects. ${ }^{96}$

A household structure that contains more members in the periphery than the core is also consistent with world systems' theory predictions about how smaller nuclearized households only become possible under conditions of intense wage dependency. More instances of adult intergenerational living in the European periphery are also consistent with the types of pressures that households that ended up in the European periphery would have been experiencing. ${ }^{97}$ Thus, the combination of being in Europe's economic periphery with having a welfare regime that puts the burden on families to provide basic welfare goods would translate into specific expected trends in terms of household structure and function, with noticeable results in labor market participation for women, and fertility rates.

At the same time, households are not only the recipients of such pressures coming from the effects of an increasingly integrated European market. Rather, they are also agents of pressure for change within national politics. Since private transfers and informal market transactions are basic mechanisms that households facing a market with high unemployment can use for survival it is reasonable to expect that there will be political pressure to retain a legal framework that is favorable to such additional sources of income. It is not surprising then to see Greece passing tax laws incentivizing the in vivo property transfers between parents and

\footnotetext{
${ }^{96}$ Spain's informal or "shadow" economy is calculated at an average of about $22 \%$ and Portugal's at an average of about 23\%. Andreas Buehn \& Friedrich Schneider, Shadow Economies Around the World: Novel Insights, Accepted Knowledge, and New Estimates, 19 INT'L TAX \& PUB. FIN. 139, 160 (2012).

${ }^{97}$ Maria Iacovou \& Alexandra Skew, Household Structure in the EU (ISER Working Paper Series, Working Paper No. 2010-10, April 19, 2010).In another study Iacovou claims to discern a preference for such living arrangements beyond the structural pressures exerted by the lack of a safety net outside the family in the European South. Maria Iacovou, Leaving Home in the European Union (ISER Working Paper Series, Working Paper No. 2001-18, November 2001). She concludes this by comparing higher income households and how they might use those resrouces to help their children. She hypothesizes that high income households with a preference for their privacy would have lower ages of children living home because the parents would be spending some of their income to help their children setup home elsewhere. By contrast households with children leaving home later would be spending money to make their children feel more comfortable at home. This discretionary preference for how to dispose the higher income cannot be explained by structural pressures and is instead a subjective preference within a culture, according to Iacovou. This conclusion however fails to ask an important question. Might there be structural reasons in the European south why parents might acquire such a preference? A first answer would be that the lack of a background safety net also means that old age dependency is equally dealt with at home or the costs absorbed by the household. Lack of stable market options and the insufficiency of the public safety net would also mean that parents in these countries know that they will need their children's help later on in life. The more resources a parent devotes to the child and the closer a bond they form, the likelier they are to get personal attention from their offspring in the old age. Having a child longer at home shapes the bond that will later help them get personal attention. The cultural preference for adult co-residence with older parents is not structural pressure free.
} 
children, nor is it surprising to see little citizen support until 2008 for the proper enforcement of tax laws against widespread tax evasion and the informal economy. ${ }^{98}$

\section{The legal construction of the household}

The Greek legal system continued to reflect the expectation that families would largely internalize basic costs of human dependency and wellbeing, including through the widespread provision of employment to family members in the family business. The Greek state's policy after accession in regards to the family business continued to be one of widespread toleration for the tax and labor law evasion that made the existence of such inefficient enterprises viable. As the economy started turning towards the services sector the micro business continued to provide the main source of employment in Greece. By 1990, 96.3\% of the 690.000 businesses in Greece employed 0-9 people. $^{99}$ Almost $91 \%$ of employed people in the non-primary sector worked for small and medium businesses, while Greece had the highest number of businesses per inhabitant than anywhere else in Europe. ${ }^{100}$ Finally, informality was the main modus operandi of the Greek family business. ${ }^{101}$

Legal incentives for concentrating responsibility for basic employment and welfare in the family could be found dispersed throughout the Greek legal system. Take the pension scheme for example. Or better, the pension schemes, ${ }^{102}$ since there was no unified social security system. Those schemes provided differing levels of old age protection to distinct categories of workers, privileging public sector workers and the liberal professions (doctors and lawyers mostly). But across all pensions schemes the basic underlying assumption was that women were either homemakers or secondary breadwinners. ${ }^{103}$

The structure of the social security system certainly continued to incentivize women in this direction. Unpaid work performed at home was not recognized as the basis for an

\footnotetext{
${ }^{98}$ The incentive lies in the preferential tax treatment of inter vivos gifts as compared to inheritance or estate taxation. In 2002, Greece reduced the tax rate for intra vivos transfers of family businesses from $20 \%$ to less than 2.4\%. See Margarita Tsoutsoura, The Effect of Succession Taxes on Family Firm Investment: Evidence from a Natural Experiment (Chicago Booth Research Paper Series, No. 12-15, December 26, 2012) (concluding that the change resulted in higher percentage of family businesses staying in family hands).

${ }^{99}$ Panagiotis Liargovas, The White paper on Growth, Competitiveness and Employment and Greek Small and Medium Sized Enterprises, 11 SMALL BUS. ECON. 201, 201 - 214 (1998).

${ }^{100} I d$.

${ }^{101}$ European Comm'n, Flexibility and Competitiveness: Labour Market Flexibility, Innovation and Organisational Performance (Flex-Com) 2 (2005), http://cordis.europa.eu/documents/documentlibrary/90882401EN6.pdf. (calculating the Greek informal sector at between $29 \%-36 \%$ of the overall economy and noting that "institutionalisation of flexible labour forms will not improve the competitiveness of small companies (which will continue to favour the informal sector)"). Additionally, microfirms, characterized by informal labor arrangements, comprise $91.8 \%$ of establishments in the Greek economy. See id. (concluding that such microfirms would continue to favor informality despite the availability of formal flexible contracts).

${ }^{102}$ Manos Matsaganis, Yet Another Piece of Pension Reform in Greece, 7 S. EuR. SOC'Y \& POL. 109, $109-122$ (2002); Manos Matsaganis, Union Structures and Pension Outcomes in Greece, 45 BRIT. J.Indus. REL. 537, 537 555 (2007); Manos Matsaganis \& Chrysa Leventi, Pathways to a Universal Basic Pension in Greece, 6 BASIC INCOME STUD. 5 (2011).

${ }^{103}$ For a discussion of all of these characteristics of the Greek social security system, see Manos Matsaganis \& Athina Petroglou, The Social Security System and Women, 8 (Center for the Research of Equality Issues, 2001) [in Greek], http://www.kethi.gr/attachments/171_GYNAIKES_SYSTIMA_KOINONIKIS_PROSTASIAS.pdf.
} 
independent right to healthcare or a social security benefit, but could only form the basis of such rights in the context of a marriage with a breadwinning male. ${ }^{104}$ In addition, women's interrupted patterns of work were not adequately accounted for, resulting in huge gaps of coverage and either no establishment of a pension right or the establishment of very minimal pension rights. ${ }^{105}$ The only mode in which women's reproductive lives were accounted for was through the establishment of a right to receive an early retirement for those women working in formal labor markets when they could show that they had previously cared for minor children. ${ }^{106}$ The structure of this explicitly gendered benefit, however, merely encouraged women to abandon labor markets at a relatively young age and at a stage when most of the care work at home had already been performed. ${ }^{107}$ Because mothers were thought of as having the right to an early retirement, their employers were given a formal legal right to fire women first, paying only $40 \%$ of the legally required compensation. ${ }^{108}$

More importantly for the Greek context where the family business continued to predominate, providing work with social security benefits to a spouse was not obligatory. In other words, family business owners could choose whether to pay contributions for the working spouses or not. ${ }^{109}$ Male family business owners, the usual title holders of the Greek family business, ${ }^{110}$ thus received a subsidy from the state in the form of permission to avoid labor law and social security obligations they would have had if they had been employing a non-family member. Not surprisingly, the vast majority of the non-insured elderly were women. ${ }^{111}$ Even the women who had no income however, could rarely establish a welfare benefit on the basis of their poverty. The welfare regime imputed income to an applicant when any family member had income equaling even the minimum welfare benefit provided for. ${ }^{112}$ Thus, the legal regime openly required the family to internalize dependency costs, penalizing of course those within the family who had the least access to resources, by restricting their exit options from the family.

Greek family law was another domain of law openly subsidizing family cohesion through the subordination of the wife's interests. Until 1983, the family law chapter of the Civil Code incorporated an openly gender unequal framework of legal relations. Those included a husband's right to make decisions as "head of household", including his right to manage the dowry brought into the marriage by the wife. ${ }^{113}$ At divorce, each spouse received property titled in one's name and an innocent wife had a right to alimony and the recovery of whatever dowry had survived the husband's management. This family law regime was overhauled in 1983 with a reform largely driven by the idea that entry into the EEC and modernization required gender equal relations. ${ }^{114}$ All language about the husband's primacy was expunged and spouses were required

\footnotetext{
${ }^{104} \mathrm{Id}$.

${ }^{105} \mathrm{Id}$.

${ }^{106} \mathrm{Id}$.

${ }^{107} \mathrm{Id}$.

${ }^{108}$ Id. at 9.

${ }^{109} \mathrm{Id}$.

${ }^{110}$ Even though exact numbers are hard to come by the relevant literature cites a preference for male children in the inheritance and management of the family business. See Daphne Halkias et al., Greece: Dreams of My Father; a Father-Daughter Succession Story in a Greek Family Firm, in FATHER-DAUGHTER SUCCESSION IN FAMILY Business: A CROsS-CulturAl PERSPECTIVE 122 (Halkias et al. eds., 2011).

${ }^{111} I d$.

${ }^{112} \mathrm{Id}$.

${ }^{113}$ Somewhat like the husband's life estate to the wife's immovable property in the common law system.

114 Tsoukala, supra note 87.
} 
to make decisions jointly.

More importantly, the property regime was also dramatically altered. The biggest change was the formal abolition of the dowry system, up until then a staple of the Greek marital property regime. Despite feminist activism demanding a move towards community property, the reforms introduced a regime of equitable distribution of marital property that involved a presumptive $1 / 3$ stake of each spouse in the other spouse's wealth accumulation during marriage at the moment of divorce. ${ }^{115}$ Theoretically the $1 / 3$ stake could be increased up to one half if the spouse could prove that her contribution to the other spouse's wealth accumulation was greater than $1 / 3$. But a spouse could also argue that the contribution had been much less than one third.

The combination of fault divorce with dowry in the pre-1983 regime translated into difficult exit options for women, who needed to be innocent parties demanding a divorce from their guilty husbands in order to recover what they had brought into the marriage in the form of the dowry. The reform, which also included a consensual divorce, theoretically made a wife's exit from marriage easier, by introducing a form of equitable distribution of wealth accumulation during marriage which could help a wife liquidate her marriage specific investments and move on. Despite the common situation of the 'homemaker' who works informally in the family business as well, courts proved to be extremely stingy in their interpretation of the new law, giving out smaller payments than even the presumptive $1 / 3$. $^{116}$

From the perspective of a government policy for informal support of the family business, this result is not surprising, as bigger payments might have forced the break up of accumulated family capital. Divorce rates remained extremely low in Greece in the eighties and nineties. ${ }^{117}$ Facing the prospect of leaving the marriage without recuperating the marriage specific capital that the homemaker had put in might have been enough dissuasion. Especially so against the backdrop of an equally stingy welfare state and widespread wage discrimination in the formal employment markets. Finally, widespread discrimination in the labor markets, rampant sex harassment, and high female unemployment, further restricted married women's exit options from a marriage, by increasing their opportunity costs.

Read together, the social security, welfare, family law, and labor law regimes created a tightly intertwined web of family regulation that incentivized family cohesion, internalization of dependency costs, and informal support for the family business.

\section{E. Revisiting the Greek crisis through the lens of household strategies}

How did Greek households react to the main economic developments after EEC accession, namely the reorganization of the productive base towards the service sectors, rising unemployment and generous compensating transfers from the Structural Funds? ${ }^{18}$ How did the

\footnotetext{
${ }^{115} I d$.

${ }_{116}^{116}$ Aspasia Tsaoussi-Hatzi, supra note 87.

${ }^{117}$ They are still amongst the lowest in Europe. See Michael Wagner \& Bernd Weiß, On the Variation of Divorce Risks in Europe: Findings from a Meta-Analysis of European Longitudinal Studies, 22 EuR. SOC. REV. 493 (2006).

${ }^{118}$ During the eighties Greece, Spain, and Portugal seem to have received close to 3-5\% of their GDP in structural funds annually. See Nicos Christodoulakis \& SARAntis Kalyvitis, Structural Funds: Growth, EMPLOYMENT AND THE ENVIRONMENT (2001).
} 
legal and regulatory environment influence those strategies? As a starting point, households facing the pressure of increased unemployment would have an incentive to complement their income through more wage work, public transfers, private transfers, market operations, or subsistence work. ${ }^{119}$

\section{Wage work}

Sending an additional member of the household to seek wage work is a common response to rising cost of life and/or diminishing wage income. Sending an additional member of the household to do wage work might be a viable strategy only if the household has resolved the problem of how to deal with the daily maintenance necessities of the household. In the alternative, part time work might be an option that allows additional income without the need to outsource the homemaking work necessary on a daily basis. Indeed, Greek female labor participation, which had been rising steadily since the seventies, continued to rise through the eighties. However, it remained very low compared to European countries that provided either market or state alternatives to care work at home. ${ }^{120}$ Educated women flooded the public sector for one of the coveted positions in the 'insiders' economy of public employment. ${ }^{121}$ These choices are really not surprising when one considers that the Greek legal and regulatory regime placed the main burden for dependency on families, without providing state services in kind, or sufficient transfers in cash to support that caretaking. ${ }^{122}$

Affordable market alternatives to family care became available in the early nineties thanks to the massive inflow of illegal immigrants from Albania and parts of the former Soviet Union. This freed more female hours for market work and allowed women's labor participation to increase further. ${ }^{123}$ Some families in the upper middle strata incorporated an immigrant nanny in the household, thus adopting a strategy of expanding the household in order to deal with the simultaneous need for more wage income and care work. The working conditions of these immigrants were exploitative, characterized by long-hours and low wages. ${ }^{124}$

Strategies in regards to children's education and employment were congruent with pressures coming from the economy and incentives coming from the Greek legal system's reinforcement of family cohesion as de facto welfare and employment policy at the same time.

\footnotetext{
${ }^{119}$ Wallerstein \& Smith, supra note 28.

${ }^{120}$ Costas N. Kanellopoulos \& Kostas G. Mavromaras, Male-female Labour Market Participation and Wage Differentials in Greece, 16 LABour 771, 771 - 801 (2002). Namkee Ahn \& Pedro Mira, A Note on the Changing Relationship between Fertility and Female Employment Rates in Developed Countries, 15 J. POPULATION ECON. 667, 671 (identifying Greece amongst "low participation rate" countries in the OECD, below 50\%).

${ }^{121}$ This would explain why married women favor public sector employment in Greece (as well as Spain and Italy). See Brindusa Anghel et al., The Effect of Public Sector Employment on Women's Labour Market Outcomes 19 (Institute for the Study of Labour (IZA), Discussion Paper No. 5825, 2011). More than 50\% of women working in the public sector in Greece have attained tertiary education. Id.

${ }^{122}$ Florence Jaumotte, Labour Force Participation of Women: Empirical Evidence on the Role of Policy and Other Determinants in OECD countries64 (OECD Economic Studies, No. 37, 2003)(“child bene-fits are very low in some countries which also have relatively low public childcare spending" including Greece).

${ }^{123}$ Antigone Lyberaki, Migrant Women, Care Work, and Women's Employment in Greece, 17 FEMINIST ECON. 103, 103 - 131 (2011).

${ }^{124}$ Gabriella Lazaridis, Filipino and Albanian Women Migrant Workers in Greece: Multiple Layers of Oppression, in Gender And Migration in Southern Europe: Women on the Move 49, 49 - 79 (Floya Anthias \& Gabriella Lazaridis eds., 2000).
} 
The next generation's education became part of the Greek household's long-term survival strategy. Greek households heavily invested in their children's education, steering an entire generation towards liberal professions such as doctors and lawyers. ${ }^{125}$ From a material perspective, the preference for the liberal professions was a good bet in an economy that subsidized small businesses and the professional class through widespread tolerance of informality and tax evasion. If the household had access to one of the coveted public sector jobs, a medical or a legal education could also be used to get access to these posts. Households that had a family business typically had one member of the next generation training to take over the business, while diversifying through the education of additional siblings in the liberal professions.

Whether children were training for the professional class or working the family business, the strategy translated into especially prolonged stays under the parental roof, stretching well into a 'child's' thirties. This can very well be the result of prolonged education along with rising unemployment and a lack of outside sources of support for setting up a new household, such as the welfare state or cheap housing loans. Indeed the rates of "children" living at home seem to have increased over the last two decades in accordance with the deterioration of unemployment conditions for the young-and not so young:

From $35.5 \%$ in 1985 to $48.8 \%$ in 1995 and $57.8 \%$ in 2005 in the $25-29$ age group; and from $21.3 \%$ in 1985 to $24.7 \%$ in 1995 and $31.6 \%$ in 2005 in the $30-34$ age group. At age 30 to 34, a staggering $43 \%$ of not-so-young Greek men still lived in the parental home in 2005 - a performance exceeding even that of their Italian counterparts $(38.3 \%)^{126}$.

Culture cannot possibly explain this trend, since Greek values, if anything, have moved in the direction of a loosening of strict sexual mores and more tolerance for alternative living arrangements in the last two decades.

With a labor market relying on a system of family contacts, and a small business environment equally reliant on the same, the strategy of shielding the younger generation from the need to work for the basic maintenance translated into more time for developing the necessary professional and personal contacts to safely launch them into their professional future. Not needing to work for your basic subsistence in your early adulthood came to stand for the family's social status, but it also made sense in terms of the type of human capital the household was trying to invest in and develop. Contrary to a market in which individuals might gain useful human capital by building all types of work into their life's experience or their cv, young Greeks in the early nineties were engaged in the process of building their family's social status, which in turn depended on maintaining the family's professional trajectory free of low-skilled, manual

\footnotetext{
${ }^{125}$ During academic year 1999/2000, one in two university students was enrolled in courses in Law, Education, Social Science or Medicine, fields which were thought to give access to public sector jobs. See Ilias Livanos \& Konstantinos Pouliakas, Wage Returns to University Disciplines in Greece: Are Greek Higher Education Degrees Trojan Horses?, 19 EDUC. ECON. 411, 411 - 445 (2011). According to one calculation, Greece has the highest rate of lawyers per capita in Europe (1:338 compared to 1:850). THEODORE KATSANEVAS, PROFESSIONS OF THE FUTURE AND THE PAST (2002) (in Greek).

${ }^{126}$ Manos Matsaganis, Social Protection of Non-Standard Work in Greece (Athens University of Economics and Business, Working Paper No. 1107, 2011).
} 
labor. $^{127}$

\section{Private transfers}

These household dynamics also help explain why despite high unemployment rates Greece continued to attract thousands of immigrants working in the agricultural sector as well as personal care and homemaking services. Intra-family transfers to the younger generations of unemployed raised the Greeks' reservation wages, meaning the minimum, wage for which a young Greek would be willing to work was much higher than the one offered in the low wage sectors of agriculture or care services. Young Greeks had access to a roof and basic subsistence through intrafamily transfers without the need to work. Greece may not have had a welfare state taking care of basic dependence needs of its society but it had a robust system of family relations that replaced it, often much above the minimum level offered in other types of welfare states. Thus, the 'paradox' of high unemployment combined with high influx of immigrants working in the worst paid sectors of the Greek economy.

Finally, another reason why the younger generation was shielded from subsistence work in their early adulthood through family transfers may have to do with the expectations of reciprocal personal care. In a system with very little in kind services from the welfare state or decent alternative from the market, such as old people's homes, the older generations rely heavily on the younger generations for the provision of personal care. Extended periods of cohabitation accompanied with generous gift giving from the parents forge the emotional bonds of love and duty that are likelier to result in personal care from one's children in one's old age. Greece has a long history of parents who 'invest' materially in one of their children, usually an unmarried daughter, with the expectation that this will result in old age care. The fact that the only alternatives to personal care by children was medicalized institutionalization for the extremely poor or senile stigmatized care outside the family for the elderly as a virtual abandonment of the filial duty to care. These norms started relaxing somewhat in the nineties when cheaper market alternatives became available through the massive influx of illegal immigrants.

The unavailability of public transfers, or better, their inconsistent availability to households on the basis of party politics, meant an overall intensification of private transfers. Besides the family law reform of 1983, which continued to favor accumulation of family capital over the splitting of wealth as marital property, tax laws on inheritance at this time also reflected the increased pressure on members of households to share. More specifically, the Greek state created preferential tax treatment for in vivo gifts from parents to children, ${ }^{128}$ which resulted in losses in tax revenue for the Greek state but also in the reinforcement of the family support networks already in place. Greek households even up until 2008 reflected a trend of

\footnotetext{
${ }^{127}$ This seems to be true even of agricultural households. For an in-depth study of how Greek agricultural households used EU agricultural subsidies and the cheap labor of illegal immigrant in order to increase their consumption levels and engage in what anthropologists call pluriactivity (rather than further agricultural specialization), see CHRISTOPHER LAWRENCE, BLOOD AND ORANGES: IMMIGRANT LABOR AND EUROPEAN MARKETS IN RURAL GREECE(2011).

${ }^{128}$ See Tsoutsoura, supra note 98.
} 
consolidation aimed at saving resources. Greek households were larger than their European counterparts. The most important feature, however, was not size but the cohabitation of two different generations of adults. ${ }^{129}$

The post-euro phase of Greek integration into the EU was characterized by a credit boom. Cheap mortgages and consumer loans became available to an unprecedented degree. Greek households, previously amongst the least indebted households in Europe increased their loan consumption, finally reaching a level of household indebtedness of about $40 \%$. Even though this rate of household debt was still low as compared to the European average it reflected household need to supplement insufficient income through borrowing. Household indebtedness eventually led to an increased rate of defaulting loans after 2009, when the flow of cheap credit from Europe suddenly stopped.

\section{Informal Market operations}

Intensifying informal market operations is another strategy households can employ when faced with less wage income. In Greece, the family business continued to operate as the main motor for employment and dependency, often operating in the grey area between formality and informality. In the early eighties family businesses in the manufacturing sector had provided an opportunity for women previously only engaged in domestic production to acquire some wages. The demise of the small manufacturing sector especially in the urban areas, reoriented many small business ventures towards the retail sector in the domestic consumption setting. Many households with some capital acquired small retail shops run by the wife now doubling as unpaid shop employee. ${ }^{130}$

Tax evasion during this time intensified, which reflects Greek household efforts to maximize their resources in the face of uncertain prospects for full wage dependency. A lot has been written in the recent crisis about the Greek 'culture' of tax evasion. ${ }^{131}$ The truth is that by the end of the eighties it had become perfectly rational to try and hide your income if you could. The state in return dealt with diminishing tax receipts through the occasional tax amnesty plus

\footnotetext{
${ }^{129}$ Iacovou \& Skew, supra note 97.

${ }^{130}$ As Labrianidis noted in his study of a northern Greek area, there was an "increase in the incidence of multiple job holding, particularly among unskilled female workers formerly engaged in domestic pursuits." Lois Labrianidis \& Christos Kalantaridis, Globalization and Local Industrial Development in the European Periphery: Enterprise Strategies in Eastern Macedonia and Thrace, 5 EUR. PlANNING STUD. 477, 477 - 494 (1997). Labrianidis' study is particularly interesting because it details the ways in which norms and expectations of behavior drawing from the domestic realm were transposed into the domain of the family business and its organization

${ }^{131}$ Greece is the typical case of a "tipping point" in tax evasion, whereby relatively high tax rates for individuals combine with low corporate rates and state corruption to produce a state of affairs where it makes sense to try to hide your income because you are not getting your euro's worth of public services. See Manos Matsaganis \& Maria Flevotomou, Distributional Implications of Tax Evasion in Greece 20, 24 (Hellenic Observatory, GreeSE Paper No. 31,2010 ) (finding that tax evasion is around $10 \%$ in the lower income strata, falls to $5-8 \%$ in the middle income strata, and sharply rises to $15 \%$ in the higher income strata). The clientelist nature of the Greek state also guarantees an asymmetric risk of punishment for tax evasion for clients as compared to non-clients. Greek politics were recently rocked by revelations that two consecutive finance ministers from 2010 to 2012 sat on a list containing thousands of names of Greek Swiss bank account holders instead of using the list to identify high value tax evaders. One of the finance ministers is being investigated for allegedly having removed names of relatives form the original list. Helena Smith, Greece's 'Lagarde list' Sparks Calls for Catharsis over Tax Avoidance, THE GUARDIAN, Jan. 7, 2013, www.guardian.co.uk/world/2013/jan/07/greece-christine-lagarde.
} 
penalties, which, however, resulted in the entrenchment of tax evasion. When and if caught, tax evaders could arrange penalty payments to the state or bribe the tax employee. Both of these options amounted to less money than the actual tax they would have had to pay before. ${ }^{132}$

\section{Political pressure}

From a political perspective the types of pressures Greek households faced since entering the EEC and their reactions to these pressures can help explain the abovementioned stasis in reforms that were theoretically already required of Greece upon entry. Facing a labor market with high unemployment and increasing precarization in working conditions, in combination with the insufficiency and inconsistency of public transfers, Greek households developed an essentially conservative strategy that included diversifying the next generation's human capital between the private and the public sectors, heavily betting on educations that could be used in either, under the assumption that the system in place would continue indefinitely. Thus, Greek households essentially contributed to the indefinite continuation of this economic system either by exerting political pressure for its preservation or by refraining from exerting political pressure for its radical overhaul.

In any case, the tiny size of the Greek labor market, combined with the tiny size of the electorate, meant that more or less every household either had a member who was participating in this "insider" economy, or had hopes that they would eventually. Diluted through the lens of family networks and households, the individual interests of winners and losers in this economy, could not be directly translated into clear political mobilization for the overhaul of this system, because the interests of the household trumped those of its individual members.

At the aggregate level, individuals were trapped in a massive collective action problem. Even if individuals would have been better off in an alternative system where jobs in the public sector were not distributed on the basis of party favors and where the state-or even the markettruly did assume the burden of basic welfare provisioning, no one could afford to assume that this is how things would work out or proceed without trying to take advantage of the opportunities offered through family network access to public sector jobs, privileging of family members in business management, widespread participation in tax evasion and labor regulation violations, and diversification of family human capital through the education of the next generation in the liberal professions. After a certain point, possibly in the late eighties/early nineties when the first post-dictatorship generation reached majority, household investments in the continuation of the current system were significant and there was already a critical mass of people reaping enough benefits from things as they were, so as to refrain from political actions in the direction of reforms.

Of course this is not to suggest that every household reaped the same benefits from Greece's political economy after accession to the EEC. The main beneficiaries were members of the elite political class, also an occupation much like the family business. They perpetuated a system of bartering votes for public sector appointments and diverted billions of euros into private accounts, in exchange for their decisions in public procurement projects, including

\footnotetext{
${ }^{132}$ Matsaganis \& Flevotomou, supra note 131.
} 
massive arms sales to the Greek army from Germany, France, and the US. ${ }^{133}$ Similarly, households with businesses that could reap the benefits of close connections to public procurement, or with businesses that could reap the benefits of massive informality in the private sector also profited tremendously. Ironically, it was the same people who were entrusted by European partners to handle the Greek loan in 2010, whose conditionality entailed a radical reversal or re-engineering of the same system that had made some of these people rich. Their interests were also organized along family lines as can be seen by the domination of the Greek political scene by three of four prominent families. ${ }^{134}$

\section{Comparative Implications: Household REgulation AND EuROPEAN INTEGRATION IN CRISIS}

The role of households in the economy was an important factor in the development of Greek economic woes. This section examines the implications of household analysis for the development of European policy after the crisis. I start with a household based analysis of the fiscal adjustment and structural reforms required of Greece and then move on to discuss the implications of this analysis for other familistic regimes in Europe, as well as for the future of European governance overall.

The starting point for the comparative part of the analysis is that Greece is not the only familistic regime of welfare provisioning. Other countries in the European periphery, such as Spain and Portugal, are similarly characterized by a type of welfarism that relies extensively on the family. ${ }^{135}$ These countries have also been intensely hit by the euro crisis and are currently undergoing programs of fiscal and structural adjustment that are similar to the Greek program. ${ }^{136}$ Thus, these regimes share characteristics both from the macro and from the micro structural perspective of household regulation. We can therefore expect that some of the analysis of the Greek case will have implications for them as well.

Furthermore, the European Union is undergoing a stage of deep institutional rearrangement, with changes effective immediately in macro economic governance, and more

\footnotetext{
${ }^{133}$ Greece has been Europe's highest spender in military procurement in relative terms for the last forty years. See Frank Slijper, Guns, Debt and Corruption: Military Spending and the EU Crisis, April 2013, http://www.tni.org/sites/www.tni.org/files/download/eu_milspending_crisis.pdf. The recent trial of former minister of Defense for corruption and tax evasion is thought to reveal only the "tip of the iceberg" in terms of private enrichment through bribes in military contracts. Rachel Donadio \& Niki Kitsantonis, Corruption Case Hits Hard in a Tough Time for Greece, N.Y. TiMES, May 2, 2012, http://www.nytimes.com/2012/05/03/world/europe/akistsochatzopouloss-corruption-case-hits-hard-in-greece.html?pagewanted=all\&_r=0;

Kevin Featherstone, Introduction: 'Modernisation' and the Structural Constraints of Greek Politics, 28 West Eur. Pol. $223,223-241$ (2005).

${ }^{135}$ Wil Arts \& John Gelissen, Three Worlds of Welfare Capitalism or More? A State-of-the-Art Report, 12 J. EuR. SOC. POL'Y 137, 143 (2002).

${ }^{136}$ Portugal has a bailout program. European Comm'n, Economic Adjustment Programme for Portugal, http://ec.europa.eu/economy_finance/assistance_eu_ms/portugal/index_en.htm (last updated May 19, 2014). Even though Spain doesn't, the structural adjustment is similar. See European Comm'n, Recommendation for a Council Recommendation on Spain's 2014 National Reform Programme, COM(2014) 410 final.
} 
projected for the near future. ${ }^{137}$ From the household perspective, this means that the macro structural conditions for all euro zone countries are undergoing a change, in ways that might impact households in different ways depending on how they are regulated at the micro level. Tighter fiscal conditions and structural adjustments might mean different things depending on the location of different households within regimes that rely primarily on the family, primarily on the state, or primarily on the market for the provision of basic welfare.

\section{A. Implications of household analysis for Greece}

In October 2012, the two chief economists at the IMF, Olivier Blanchard and Daniel Leigh publicly admitted that the effects of fiscal consolidation on growth had been dramatically miscalculated by the IMF. ${ }^{138}$ They elaborated with a January 2013 paper that provoked political ripples in Europe. ${ }^{139}$ The depth of the recession is something that the Greeks certainly knew in their skin by 2012 . The initial 2010 program projections expected an initial recession, quickly followed by a moderate but steady return to growth. ${ }^{140}$ Instead what Greece has gotten is a much deeper recession that is still ongoing and whose repercussions are tearing the Greek social fabric.

Employing a household analysis might have helped the troika predict that the impact of fiscal austerity would have been much worse than predicted. Even for a believer in the power of 'labor flexibilization' to deliver growth, the labor reforms were especially tone deaf as far as the Greek economy goes. ${ }^{141}$ The private sector was already characterized by massive wage flexibility, as well as significant flexibility in hiring and firing. Besides, the part of the economy that was within the reach of labor law at all was tiny. The majority of Greek businesses were

${ }^{137}$ For an exposition of the main elements of the new macroeconomic governance framework in the EU, see
European $\quad$ Comm'n, EU Economic Governance, http://ec.europa.eu/economy_finance/economic_governance/index_en.htm (last updated Mar. 13, 2014).

${ }^{138}$ Int'1 Monetary Fund, World Economic Outlook: Coping with High Debt and Sluggish Growth (October 2012), http://www.imf.org/external/pubs/ft/weo/2012/02/pdf/text.pdf; IMF Details Errors in Calling for Austerity, WALL ST. J. BLOG (Jan. 3, 2013, 3:28 PM), http://blogs.wsj.com/economics/2013/01/03/imf-details-errors-in-calling-forausterity/.

${ }^{139}$ Olivier J. Blanchard \& Daniel Leigh, Growth Forecast Errors and Fiscal Multipliers (Nat'1 Bureau of Econ. Research, Working Paper No. 18779, 2013). For the reaction of the European Commission's Vice President, see Letter from Olli Rehn, Vice-President, European Commission, to ECOFIN Ministers (Feb. 13, 2013), available at http://ec.europa.eu/commission_2010-2014/rehn/documents/cab20130213_en.pdf.

${ }^{140}$ EAPGR1, supra note 61.

${ }^{141}$ Structural adjustment in the form of labor flexibilization has been challenged as a one-size-fits-all recipe for growth. The OECD originally introduced the idea that labor regulation was largely to blame for high levels of unemployment in developed countries. See ORG. FOR ECON. COOPERATION \& DEV., THE OECD JOBS STUDY: EVIDENCE AND EXPLANATIONS (1994). After more than a decade of policy recommendations and reforms the OECD reviewed and significantly revised its original Jobs Strategy Report. ORG. FOR ECON. COOPERATION \& DEV. (OECD), OECD EMPLOYMENT OUTLOOK: BoOsTING JOBS AND INCOMES (2006). The 2006 revision noted that "the effect of E[mployment] P[rotection] L[egislation] on overall unemployment is probably small." Id. This was a far cry from the former casual observation that countries with "stringent legislation generally have a high rate of longterm unemployment.” Org. FOR ECON. CoOperation \& Dev., The OECD JobS Study: Evidence And EXPLANATIONS (1994). Even more importantly, the OECD seemed to admit that the Anglo-Saxon model with low benefits and low investment in training programs for the unemployed yielded the same results as a system with generous unemployment benefits along with active labor market programs. Finally, the 2006 report observed that even though simple economic rationality suggests that minimum wages would lead to less output and less job creation, the evidence was "mixed" and "ambiguous." See ORG. FOR ECON. COOPERATION \& DEV., OECD EMPLOYMENT OUTLOOK: BOOSTING JOBS AND INCOMES (2006). 
micro enterprises, family owned and operated, working almost entirely outside the purview of labor law. Forcing those businesses to comply with labor and tax legislation equaled their effective closure. Their survival was almost entirely dependent on massive amounts of tax and labor law violation or avoidance. The fact that thousands of these businesses closed in the face of a credit squeeze and a sudden tax hike, either because of the rise in the actual rates or because of the initialization of enforcement for the first time, is entirely unsurprising.

The fact that the troika was partly aiming at reducing Greece's trade imbalance with other euro zone countries through internal devaluation means that the short-term result of sudden, massive rise in unemployment could not have been a surprise to the troika either. Daniel Gros, director of a European think tank that has the ears of EU institutions, admitted as much in a surprisingly candid interview with Greek newspaper Kathimerini:

In a country like Greece, with high external debt and high current accounts deficit, there needs to be a reallocation of economic resources from the non-tradable sector to the tradable sector, to exports. This change does not happen by the government pressing a button. It happens when people go bankrupt, despair and seek something new that will give them income...For the moment the more unemployed, the better. Too many are still employed in the non-tradable sectors and therefore are not contributing towards exiting the crisis. ${ }^{142}$

In the rest of the interview he stressed that in the case of Greece where there are no big industrial sectors and where the formal law on the books was not as important, "the labor market was not a central problem." ${ }^{143}$ However, he added that reforming the labor markets "could not hurt" because it would lead to the liquidation of the current model, which in turn would force more people to seek employment in the export oriented industries. ${ }^{144}$ Even assuming then that part of the goal of the proposed and achieved labor reforms was indeed short-term unemployment forcing people to seek employment in export oriented sectors, a household based analysis is still crucial in figuring out whether the expected result could be reached.

The first observation in this direction is that the troika program amounted to a sudden, simultaneous pressure on wage income for households, with drastic wage cuts for the employed and massive loss of employment overall. In addition, it also meant a dramatic tax hike, especially for the part of the population that was wage dependent and therefore not as able to evade taxes, as the self-employed or the small business owners. This would mean a sudden pressure on households to increase their income through private transfers, public transfers, subsistence work and informal market operations.

Pressure on Greek households to complement their dropping income through private transfers would easily translate into more intra-family transfers and an intensification of the family as the only reliably existing safety net. In Greece then, a worker's reservation wage, the

\footnotetext{
${ }^{142}$ Yiannis Palaiologou, E Litoteta Hetan He Mone Dynatoteta Gia Ten Hellada (Austerity Was the Only Option for Greece) EKATHIMERINI, July 14, 2013 (author's translation) http://news.kathimerini.gr/4dcgi/_w_articles_ell_2_14/07/2013_526736. 
minimum income for which she would prefer taking a badly paid job to being unemployed, would depend on the amount of intra-family transfers available. Thus, household more than individual income would determine the success of the troika's resource reallocation program.

Intra-family transfers seem to have indeed kicked in since 2010 as the only reliable safety net. More and more people in the upper ages of youth (35 or so) have moved back into their parents' household. ${ }^{145}$ There is anecdotal evidence of families of young unemployed with their infant children living on a retired parent's minimum pension. ${ }^{146}$ Even though the number of homeless people in Athens has dramatically increased since 2009, the fact that there aren't more homeless in a city with skyrocketing unemployment can be clearly attributed to the family as safety net.

In addition, the fact that many Greek households can still afford to keep their homes in such dramatic economic conditions is the result of the high homeownership ratio in Greece. This ratio in turn can be attributed to post-WWII housing policy and inheritance laws that strongly favor intra-family transfers. After WWII, the Greek state created a legal framework that allowed small landowners to exchange their land for apartments in newly constructed buildings. This was an essentially "self-financing" scheme that needed almost no credit in its realization, and which in turn resulted in a housing boom, boosting demand and contributing to growth. ${ }^{147}$ Inheritance laws similarly favored intra-family transfers, establishing obligatory portions for direct descendants and thus limiting the assets that could be disposed outside of the family. ${ }^{148}$

Thus, Greece ended up with one of the highest homeownership rates in Europe, which was financed almost entirely outside the formal credit system until entry into the euro. ${ }^{149}$ Entry into the euro allowed the interest rates to drop, which in turn made available mortgages at affordable rates, previously almost entirely unavailable. This increased household indebtedness between 2000-2009, and it did result with a high number of households facing default and eviction from their homes starting in 2010. The number of households owning a home mortgagefree however remained high in 2010. We can safely hypothesize that the high homeownership ratio is one of the main factors standing between many Greeks and acute poverty, including homelessness.

Indeed, the troika seems to have noticed the high homeownership ratio in Greece not as a safety valve that is keeping many people from abject poverty but rather as one of the factors keeping home prices stable, thus standing in the way of internal devaluation, via general demand depression. It also seemed to stand in the way of labor mobility. In 2011 the troika demanded an increase in property taxes, which were deemed generally very low and insisted that this would

\footnotetext{
${ }^{145}$ Stephan Faris, Greece's Unemployed Young: A Great Depression Steals the Nation's Future, Bus. WK., July 25, 2014, http://www.businessweek.com/articles/2013-07-25/greeces-unemployed-young-a-great-depression-steals-thenations-future.

${ }^{146}$ Dimitra Manifava, One in Two Households is Supported by Pensions, EKATHIMERINI, Jan. 23, 2014, http://www.ekathimerini.com/4dcgi/_w_articles_wsite2_1_23/01/2014_536764.

${ }^{147}$ Pagoulatos, supra note 73 , at 37.

${ }^{148}$ Testamentary freedom in Greek inheritance law is limited to the extent that the law requires certain portions of wealth to be distributed within the immediate family, starting from the descending and moving onto the ascending and lateral lines. Astikos Kodikas [A.K.] [Civil Code] A: 1710 - 2035 (Greece).

149 JUDith ALLEN ET AL., HOUSING AND WELFARE IN SOUTHERN EUROPE 16 (2004).
} 
contribute to a fairer distribution of the loan's burdens. ${ }^{150}$ Property taxes in Greece were organized on a one-time transaction basis, upon transfer, selling and buying, rather than on a recurrent, yearly basis. This means that property ownership was affordable to a wider spectrum of the population. This taxation scheme was part of the same package of regulatory incentives that promoted the construction boom in the fifties, sixties, and seventies.

In its 2012 Annual Growth Survey, which concerns the entire euro zone, the Commission argued for a reform of national taxation laws away from transaction taxes on property and towards a recurrent property tax. The Commission noted that this would "enhance labour mobility and the efficient allocation of the housing stock" ${ }^{151}$ Presumably the efficient allocation of the housing stock would be achieved because only people who could afford to pay yearly taxes would be allowed to own homes. Anyone unable to pay a yearly property tax would be forced to sell the house to someone willing and able to pay for it. Of course, this means that the unemployed, after failing to pay yearly property taxes, would need to sell their homes and might face a housing conundrum. But needing to pay a yearly property tax would also lower the unemployed workers' reservation wages, making the unemployed willing to work for less, which is why the Commission thought that switching to recurrent property taxes would enhance labor mobility. Already since 2006 EU policymakers had observed that the high incidence of home ownership in Greece was standing in the way of geographical mobility of the labor force. ${ }^{152}$

The second review of the program by the troika in May 2013 included the establishment of a property tax that would ensure annual revenue, which the Greek government undertook to enforce as part of the loan's conditionality. ${ }^{153}$ At the same time, the Greek government adopted legislation that made it easier for the state to expropriate homeowners on the basis of unpaid tax bills. ${ }^{154}$ Continuing with the hypothesis that the troika is well aware of the effect of Greek household structure and function in the economy, liquidating homeowners through expropriations for unpaid tax bills is a very effective way of reducing the Greek household's capacity to withstand external income pressure through intra-family transfers and subsistence work. The more households lose capacity to cover their members' basic needs through various sources of income, the more individuals there will be whose reservation wages will be low enough to attract potential employers.

Reducing household capacity to absorb external shocks through internal redistribution in this way is of course quite a dramatic proposition with immense political and social implications. In the absence of any alternative safety net the results of challenging households like that could be dramatic. The troika of lenders has announced plans to establish a minimum public safety net

\footnotetext{
${ }^{150}$ EAPGR2, supra note 10 , at 9

${ }^{151}$ European Comm'n, Annual Growth Survey 2012, COM(2011) 815 final, Annex 4 at 5.

${ }^{152}$ Dimitris Karantinos, Greece, Contribution to the European Employment Observatory Autumn Review 2006: Flexicurity at 3 (2006), http://www.eu-employment-observatory.net/resources/reviews/Greece-FlexicurityAR06.pdf.

${ }^{153}$ European Comm'n, The Second Economic Adjustment Programme for Greece: Second Review 29 (May 2013 )

${ }^{154}$ While the bill allows for eventual foreclosures on the basis of tax bills, the passing of the bill was so controversial that the government lost one member of parliament in the process. Additionally, the government was forced to extend the freeze on such foreclosures until the end of 2014. See Nektaria Stamouli and Stelios Bouras, Greek Government Passes New Property Tax Legislation, THE WALl StreEt JouRnAl (December 21, 2013) http://online.wsj.com/news/articles/SB10001424052702304866904579272000551853972
} 
even though it has also recognized the practical difficulties of doing so under the current fiscal circumstances. ${ }^{155}$

Given the small chances of such a safety net being established the troika's program of wage decreases, and tax hikes, surely puts pressure in the direction of intensification of private transfers as well as subsistence work. This means that a very likely result of the austerity program will also be an increase in the number of women, traditionally taking care of infant and old age dependency, retreating from the market as potential wage earners. This is exactly the opposite result from the one desired by the troika program, which repeatedly emphasizes how labor reforms are meant to allow more young people and more women to enter the labor market. While the need for more wages might normally send more household members out into the market looking for wage work, a rise in unemployment that amounts to a collapse of the labor markets combined with austerity programs that have significantly reduced the already limited welfare budget, means there is much less leeway for women to enter the labor market. Faced with low opportunity costs-since jobs are scarce to begin with- more women may choose to stay home and take care of dependents. ${ }^{156}$

Finally, the dramatic drop in household wage dependency means an intensification of informal market operations. Indeed, the incentive here is to try and avoid taxes and formality in order to survive. The fact that thousands of businesses have closed as a result of the state's effort to reduce tax evasion and impose labor law enforcement confirms the incentive for the remaining ones. This of course is in tension with the program's avowed goal, but is perfectly expected based on household dynamics.

\section{B. Implications of household analysis for Europe}

The Greek case is admittedly the most dramatic in terms of the fiscal adjustment demanded of the country. Fiscal adjustment and structural reforms, however, are now undertaken in every euro zone country through the process of the European Semester or through loan agreement conditionality in the cases of Portugal and Ireland. What can the framework developed here tell us about the expected results of such economic governance?

A first lesson is that the effects of uniform measures conceived at European level might differ significantly depending on the background regimes that define the household's capacity to absorb pressure on its wage dependency coming from conditions of fiscal austerity. Take the example of the European Commission's repeated worry about workers' high reservation wages standing in the way of more market participation. ${ }^{157}$ The framework developed here would

\footnotetext{
${ }^{155}$ European Comm'n, The Second Economic Adjustment Programme for Greece: First Review 46 (Dec. 2012), http://ec.europa.eu/economy_finance/publications/occasional_paper/2012/pdf/ocp123_en.pdf ("However, given the fiscal constraints, it will take some time until Greece can afford a more extended publicly-funded social safety net.").

${ }^{156}$ KERRY RITTICH, RECHARACTERIZING RESTRUCTURING: LAW, DistribUtion AND GENDER IN MARKET REFORM (2002); Lizzie Davies, Greek Crisis Hits Women Especially Hard, THE GuARDIAN BloG, June 15, 2012 1:05 PM), http://www.theguardian.com/world/greek-election-blog-2012/2012/jun/15/greek-crisis-women-especially-hard.

${ }^{157}$ In the case of the Irish loan conditionality, the European Commission explicitly recommended lowering the minimum wage so that more Irish workers might take up available jobs in the market. Similarly, France has been warned to watch out for possible detrimental effects of its minimum wage on French workers' reservation wages.
} 
suggest that it is the countries that have more dependency on the family for welfare, and more capacity to intensify informal operations and subsistence work without the state noticing or being able to react effectively, that would be better able to preserve higher reservation wages through intra-household transfers. Paradoxically, those would also be the countries with higher unemployment rates, where one would expect the unemployed to happily take whatever job available. As long as households retain some capacity to maintain their members' standards of living through private transfers, the Commission's hoped for result, more uptake of low wage jobs in the market by the unemployed might remain unfulfilled.

The implications of this run much deeper than a simple observation about the potential efficacy of a supposedly technocratic measure. For measures aimed at the labor market to work just as the EU intends them to, there are deep changes needed in the regulation of households and the limits of the state. In other words, measures that are allegedly aimed only at market reform, in reality seek to transform the basic dividing lines between the household, the market and the state, lines that may have been drawn very differently in each member state. The goals of creating more "dynamic markets", more "labor mobility" and reorienting the economies of the European periphery towards export led growth entail the overhaul of prior regimes of welfare provisioning in the member states. In addition, such measures can never really be merely technocratic, as they entail a renegotiation of basic political bargains in each member state. Moreover, trying to move basic welfare provisioning from the household to the market in the European periphery, necessarily translates into an effort to dramatically reduce the household's capacity to support members. More markets in this case necessarily passes through a lot of social misery without much by way of a compensating mechanism.

Take the example of Portugal. Portugal, like Greece, received a bailout conditioned on the performance of fiscal and structural reform targets. ${ }^{158}$ Its economy was also largely based on domestic consumption run by family owned businesses. Households were also subsidized by the state through a series of measures strewn all over the legal system, such as tax incentives and housing regulations. Portugal's housing market was a particular target for structural reforms from the onset of the bailout program. ${ }^{159}$ More specifically, the troika thought that part of the problem in the Portuguese economy came from skewed incentives towards homeownership, such as the mortgage interest deduction from personal income tax, ${ }^{160}$ which created a wave of expensive constructions in the suburbs. At the same time, the troika thought that Portugal's rent control regulations had caused the disinvestment of landlords from the rental market and the dilapidation of urban centers. The combination of tax incentives towards home ownership and rent control had skewed markets in favor of construction and shrunk rental markets, a situation which contributed to a labor force that was not very mobile.

Here's how the European Commission described the aims of the program:

Reviving the dysfunctional rental market will improve households' access to housing and foster labour mobility. Rental regulation is cumbersome, tenant protection is very strong and eviction procedures difficult and slow, hampering the functioning of the rental

\footnotetext{
${ }^{158}$ See European Comm'n, Economic Adjustment Programme for Portugal (Occasional Papers 79, June 2011)

${ }^{159} \mathrm{Id}$. at 87.

${ }^{160} \mathrm{Id}$. at 88 .
} 
market. A large number of apartments in city centres remain empty, causing a substantial waste of capital as well as additional costs in terms of welfare, equity, transport, and environment. The lack of a rental market hampers geographical labour mobility and contributes to a high structural unemployment rate. This situation, as well as tax incentives, has encouraged house purchases and the building up of household indebtedness. ${ }^{161}$

In response to these program requirements, the Portuguese government passed the New Urban Lease law as part of its program conditionality, which abolished rent control and provided incentives for landlords to refurbish their dilapidated properties. One of the main features of the law is the transformation of the eviction processes for tenants, creating extra-judicial ways of eviction in order to speed the process, and ending extensive tenant rights, such as the right to maintain the same rental rate for each renewal period or the right to pass on the lease to a family member. Finally, the Portuguese state abolished the mortgage interest deduction from personal income taxation.

In its eleventh review of the Portuguese program, the European Commission noted that there was anecdotal evidence that the rental reform was starting to show signs of impact, with rental rates increased for contracts formerly under rent control, more rental housing since many properties came in the rental market and signs of increased tenant mobility. ${ }^{162}$ The troika charged the Portuguese government with getting more information about the impact of the reforms, worrying especially about rental income tax evasion and the actual effects on tenant mobility. The review noted that the information should help decide whether more measures might be needed to make the housing market "more dynamic."163 Finally, the Portuguese government undertook to change its property taxation, exactly like the Greek government, from a one-off transaction based property tax, to a recurring property tax system. ${ }^{164}$

If we were to translate these market reforms in household terms, we would first observe that Portugal's housing and rental market policies, seem to have been integral part to its familistic welfare regime, in which households were given subsidies in the form of rent control, and later, when access to credit through the euro became widely available, through the interest deduction from personal income. This mode of allowing households to take care of their members created a lot of inefficiencies, such as disinvestment from city centers. It was, nonetheless, a regime that allowed households to subsist in an environment with high structural unemployment. The low rents in rent-controlled areas seem to have resulted in the perverse effect of some well-off families paying rental rates with market prices of thirty years ago. However, for the 250,000 households in old rental contracts, with an average age of $60,{ }^{165}$ the overhaul of the previous regime means they are facing the potential of being dispossessed, with labor mobility becoming a moot point in their case.

\footnotetext{
${ }^{161} I d$. at 26.

${ }^{162}$ See European Comm'n, Economic Adjustment Programme for Portugal: Eleventh Review 45 (Occasional Papers 191, April 2014).

${ }^{163} I d$.

${ }^{164}$ European Comm'n, Economic Adjustment Programme for Portugal, supra note 158.

${ }^{165}$ Andrei Khalip, Analysis: Portugal rent reform aims to save builders from collapse, ReUTERS (May 13, 2012) http://www.reuters.com/article/2012/05/13/us-portugal-housing-reform-idUSBRE84C05M20120513
} 
Measures aimed at creating more 'dynamic' markets and which potentially deeply alter the fundamental welfare structures are not only envisioned in the European periphery through bailout conditionality. The European Semester's country specific recommendations encompass reforms aimed at creating more dynamic markets and more labor mobility almost throughout the euro zone. The Netherlands, for example, a country that has weathered the euro crisis relatively well, is currently undergoing a reshaping of its own housing and rental markets at the recommendation of the EU. Just as in the cases of Greece and Portugal, the European Commission is recommending abolishing the tax subsidies to buying a home and abolishing regulations that restrict the rental markets. ${ }^{166}$ Contrary to the familistic regimes of Greece and Portugal, where the state subsidized household's access to housing through tax incentives and rent control or other indirect regulation, the Netherlands directly operates a system of social housing provided by Housing Associations. Housing associations are public entities engaged in selling and renting housing to needy citizens. In other words, in the Netherlands, the state directly provides certain services to households, which in other countries would be provided by private markets or by families.

A 2012 paper by European Commission staff on the housing market in the Netherlands already sketched out some of the changes in the Dutch social housing system that would be later on recommended through the European Semester:

In the rental market, a reform to help improve its functioning should allow a more market-oriented pricing mechanism by reconsidering rent ceilings and rent indexation, scaling down the very large social housing segment and reviewing the operation of social housing corporations, increasing their effectiveness, efficiency and transparency... Labour mobility would also be enhanced by reforming the social housing system. Those in social housing often face substantial marginal costs when they wish to move, because of the ensuing loss of the entitlement to social housing. Furthermore, the current system lacks appropriate incentives to ensure that people who live in social housing and see their income increase move on, thus reducing the options for those who are in objective need of affordable housing. Focusing the provision of social housing on those who really need it and facilitating moving would improve human capital allocation. On balance, the current set-up crowds out the private rental market and limits its size, impeding its buffer role also with respect to the purchase segment. ${ }^{167}$

The problems that the report identifies are similar to the ones spotted, for different reasons in Portugal. It is argued that the very large social housing segment crowds out private rental markets and that the structure of the system disincentivizes people from moving around for the purposes of taking up a job. The European Commission recommended abolishing the tax incentives to home ownership and liberalizing rental markets in its 2013 recommendations to the Netherlands, suggesting that the reforms thus far were not going through fast enough. The Dutch government responded in 2014 with a series of measures, including reforms in the mortgage deduction, the liberalization of rental prices and a fundamental restructuring of the social housing

\footnotetext{
${ }^{166}$ Recommendation for a Council Recommendation on the Netherlands' 2013 National Reform Programme $\operatorname{COM}(2013) 369$ final.

${ }^{167}$ Windy Vandevyvere and Andreas Zenthöfer, The housing market in the Netherlands 26 (European Comm'n, Economic Papers 457, June 2012)
} 
sector with the goal of bringing social housing rental prices close to market prices and shrinking the size of the social housing rentals in favor of private market rentals. ${ }^{168}$

Some observers have already noted that the combination of these measures are likely to create a segment of the middle class population who will be priced out of both social housing and owning. ${ }^{169}$ They warn that the prediction of a more dynamic private rental market has so far not been realized because big institutional investors have preferred other markets outside of the Netherlands. This segment of the lower middle class is therefore likely to face an insufficiently supplied private rental market, with rents that are not affordable to them, at the same time as unemployment has increased and less full time employment is available.

By contrast to the Portuguese and Greek cases, the reforms in the Netherlands are aimed at less state and more market-rather than less household and more market- in the provisioning of basic services such as housing. What seems to be happening so far, however, is a reduction of the share of the state in the provisioning of these services to a specific segment of the population without the market necessarily being able to pick up the leftovers. In household terms, lower middle income households in the Netherlands are experiencing pressure on their incomes not only from the rising unemployment, but also from the withdrawal of the state from services previously provided to them. For as long as the market does not allow an affordable solutions to these individuals, solutions are likely to be sought within households:

Due to the stricter rules on mortgages and the rapid proliferation of flexible employment contracts and self-employment status, owner-occupied homes for the middle classes are becoming less accessible, unless parents or friends can help out financially. ${ }^{170}$

The supposedly neutral measures coming from euro area governance are specifically aimed at transforming basic schemes of dividing responsibility for welfare between the household, the market and the state in favor of more market. Whether this is a good thing, a bad thing, a legitimate or an illegitimate thing, is a separate discussion. But it certainly isn't as simple as assuming that there are already market structures, or state structures, all around Europe, and all that needs to be done is tune them up so that people will become more mobile. In fact, the transformations required in each case are more reminiscent of countries transitioning towards a market economy after the collapse of the Soviet Union. Only in Europe's case, each country is transitioning from very different starting points in regards to how the line between households, markets and state had previously been drawn.

Without of course hoping to address all the possible scenarios of how such transitions might play out given the household analysis offered in this article, I would like to end with an outline of some of the possibilities.

\footnotetext{
168 The Ministry of Economic Affairs, The Netherlands, National Reform Program 2014 at 17, http://ec.europa.eu/europe2020/pdf/csr2014/nrp2014_netherlands_en.pdf

${ }^{169}$ Hugo Priemus, The Future of Social Housing: The Dutch Case, 9 Co-OPERATIVE MANAGEMENT 13 (2013).

${ }^{170}$ Peter Boelhouwer and Hugo Priemus, Demise of The Dutch Social Housing Tradition: Impact of Budget Cuts and Political Changes, Journal OF Housing AND THE BuILT ENVIRONMENT 1 (2014).
} 
The first scenario that needs to be contemplated is the continuation of the current status quo in terms of policies of choice at the EU level. Those policies include significant fiscal retrenchment for most euro zone members for the purposes of complying with the $3 \%$ limit on budget deficits. They also include structural reforms aimed at reducing the role of the state in the provisioning of welfare in favor of more markets, or inversely increasing it where households previously provided it, again in favor of more markets. Notably, these policies are not accompanied by significant monetary transfers, but are rather thought of as in themselves likely to generate growth in the long-term, and desirable precisely in order to avoid the need for such transfers, which at the moment remain politically unpalatable in the countries that could afford them.

The analysis previously offered provides a glimpse into what the further development of this scenario might bring about. Countries in the European periphery like Greece and Portugal, which share both a familistic welfare regime and bailout program conditionality, are already struggling with reforms that for the moment are diminishing the capacity of households to provide welfare to their members, while at the same time the capacity of the state to substitute is limited through severe budget constraints. Markets on the other hand, are still not generating enough employment to provide a substitute for either the market or the household. Finally, the particularly dire demographics of the European periphery suggest that even if we were to imagine a scenario in which rebounding markets would eventually create more positions of employment, there would still be significant losers from this transition, who would not necessarily be able to take advantage of new opportunities in the market.

But even countries without the fiscal and conditionality straightjackets of bailout countries would face significant problems of transition. The example of the Netherlands is apt. The country has recently started to grow again, but domestic consumption remains sluggish and unemployment remains at levels much higher than before the crisis. Reforms undertaken by the government in the labor market, in pensions, in health care, and in the housing market are likely to increase pressures on households, just like in the European periphery. Despite not being a fiscal offender, the Netherlands is still going to be transitioning to a new regime of welfare provisioning which aims to put markets rather than the state at the center. There are still likely losers from this transition, whose compensation will depend on how much leeway for redistribution the country acquires, which in turn depends on how much its export economy will rebound in the coming years-the $3 \%$ fiscal straightjacket will remain constant under current EU rules.

Households in the European periphery faced with intense pressures on their income coming from a market situation which does not generate enough employment, and a tax, labor, and credit situation that no longer allows small, family owned businesses to sustain their members, will resort to several strategies. Immigration out of the country is one of them and it seems to be already underway in a significant way. Short of immigration households can try to send an additional member of the household for market work, even though the labor market might not be able to sustain them. The pressures to increase informal market operations and shield income from the taxman will increase, going against efforts to fight tax evasion and informality. 
Potential effects under this scenario also need to be examined from the gender perspective. ${ }^{171}$ Households under pressure to supplement their dropping income would seek to intensify subsistence work at home, such as various forms of personal caretaking and homemaking. This would likely increase pressure on women, many of whom have ended up from being a secondary breadwinner to being the only breadwinner after the loss of a full time job by a partner or spouse. One possible release valve from this pressure could be the exploitation of illegal immigrant labor, which to some degree is already happening. Another might be an attempt to diminish the caretaking responsibilities by postponing or avoiding reproduction. This tendency seems to be already underway in Greece. For the working women who do have children, they are relying extensively on the help of family members other than their husbands, often their mothers.

If the labor market were to recover and start generating full-time jobs, perhaps these tendencies would not have negative gender effects, as more female labor participation might produce significant political pressures for the improvement of labor conditions for women, including the eradication of gender discrimination and sex harassment in the markets. However, the macro economic outlook for the European periphery is not looking very bright so far, plus the changes in the labor market are setting the stage for a job-thin recovery. Assuming this macroeconomic scenario pans out the gender effects of challenging the household's capacity to provide welfare to its members without a sufficient state net replacing it are likely to be regressive. Female unemployment is already much higher than male unemployment and labor conditions for women have significantly deteriorated.

Countries with better macroeconomic and fiscal prospects, might be able to deal with the shocks of changing fundamental welfare structures better than in the periphery. For Europe as a whole, however, this might simply mean a further gap between the different economies of the euro zone. For the designers of current European policy, the prospect of mass migration from the European periphery to the European core may not be such a problematic case; in fact, it may be exactly what the euro zone needs in order to rebalance the economies of its different regions. If Greece's surplus doctors migrated to the German countryside which experiences a deficit of medical professionals, Greece's unemployment would improve and inflationary pressures to the German economy would also be eased. However, it seems that migration outside of the euro zone is happening as much if not more as within the euro zone, a scenario that impoverishes the European periphery without necessarily the benefit of rebalancing the European economies.

The broader point is that the effort to create welfare regimes where people rely more on the markets than they do on the state or the household might prove difficult or even backfire, depending on each country's starting point and how much leeway households in each country have to absorb the pressures coming from such a transition. The gender effects might also prove to be regressive, depending on several other factors such as whether the markets are generating enough jobs, and whether there are alternatives in place for caretaking responsibilities.

\footnotetext{
${ }^{171}$ Francesca Bettio et al., The Impact of the Economic Crisis on the Situation of Women and Men and on Gender Equality Policies, European Comm'n (Dec. 2012), http://ec.europa.eu/justice/genderequality/files/documents/130410_crisis_report_en.pdf.
} 
This leads to the second scenario, which is a continuation of current macroeconomic and structural reform policies, backed, however, by much more robust measures aiming at dealing with the transitional fallout from such fundamental changes. In countries where the households used to internalize most of the costs of dependency, a minimum provision of basic services needs to be in place, especially in the face of weak labor markets and anemic growth. Theoretically, some of the reform programs in the European periphery provide for the establishment of such safety nets where none were previously available. However, given the fiscal situations, the reality is that it will take a very long time before any such safety net can be put in place. Without additional transfers from surplus countries, the establishment of minimum state safety nets will prove extremely difficult.

The household analysis developed in this paper suggests the possibility that perhaps a third scenario might prove necessary for the future of the euro zone. If it is indeed true that the same structural reforms designed at EU level have very different results in each member state depending on the background regulatory regimes that define the lines between the family, the market and the state, then it follows that simple harmonization of the welfare regimes in the mode of soft governance will no longer suffice. In this scenario, taxation and social security at the very least would probably need to be moved to the EU level, so that incentives for entering or exiting labor markets are unified.

Of course, as of the moment of this writing, it seems that only scenario one is currently in the realm of the politically possible, which makes it the likeliest outcome. From the perspective of the social costs of structural reform, but even from the perspective of the future of the euro zone, it is the worst of all possible worlds.

\section{CONCLUSION}

This paper develops a theoretical framework for analyzing the network of legal and regulatory regimes impacting the role of households in the overall economy. It draws from a variety of fields including economics, feminist theory, legal realism, and world systems' theory, to construct both a micro and a macro perspective on the interaction between households and the background legal regimes that affect them. It argues that in order to properly understand the role of the household in the economy one needs to have a grasp of the background legal regimes that affect bargaining conditions between household members, but also an understanding of how a specific regime distributes responsibility and costs for daily maintenance and reproduction between the household, the market, and the state.

The article argues that in the case of Greece, the role of the household in the overall economy was the elephant in the room disregarded by academics and policy analysts alike in the recent crisis. It pursues an inquiry into the regulation of the Greek household before and after accession to the EU. It concludes that with the help of a host of legal and regulatory incentives, the Greek household became one of the main mechanisms for the distribution of resources in post-war Greece, in both the public domain, and the private domain, where the family business continued to provide the only available alternative to welfare. European market integration was accompanied by rising unemployment rates and a pool of money intended to ease the pressures of adjustment for the least developed regions of Europe. 
The reaction of Greek households to those pressures and opportunities was an intensification of the informality that made the inwardly looking micro-family business a viable survival strategy, a partial increase in female labor participation, particularly in 'flexible' employment and the public sector, exploitation of cheap migrant labor in the household, and an intense investment in the human capital of the next generation towards the liberal professions. The Greek household was also a crucial mechanism through which individual interests for a less clientelist and corrupt system were diluted against the weight of household interests in the continuation of the same.

Finally, the article argues that the troika of lenders' conditionality initially failed to take into account the informal welfare regime of the family, thus overestimating the immediate impact of austerity measures on the workers' reservation wages. At the same time, overlooking the family business meant underestimating the immediate impact of austerity coupled with tax hikes on the viability of thousands of such businesses, which had depended on tax evasion and informality for their survival. Similarly, the troika's labor flexibilization conditionality was particularly tone deaf in an economy mostly comprised of an already super flexible work force employed informally in the family business or in the formal private sector already flexible since the late nineties.

The article argues that the troika seems to have lately woken up to the realities of the role of households in Greece, attacking, however, their capacity to provide welfare without replacing this function with any viable alternatives. In the face of rising unemployment, a collapsed credit market, and a near collapsed labor market, Greeks are likely to turn even more towards informality, and household subsistence work, both of which are directly against the goals of enlarging the tax base and encouraging more female participation in the labor markets. Finally, if the troika insists on a program of property expropriations for the sake of inducing more labor mobility in a situation where there is no emerging market or state solution for the dislocation caused potential scenarios may involve massive migration along with the political and social instability that comes when a scheme of social relations is destroyed without any real contender taking its place.

The lesson for Europe overall is that the project of market integration, especially in the post-crisis era, has deeply affected basic structures of welfare provisioning in the European periphery. Greece may be the hardest of cases but fiscal austerity and structural reforms are now demanded of every member of the euro zone. The goal of some of these reforms is to transfer more of the responsibility for basic dependency from the state or the household to the market. Without appropriate support, however, these reforms are likely to provoke more reliance on the household rather than market, especially in the European periphery and perhaps even in the European center, depending on each state's leeway for deficit spending. More is being demanded of households at the same time that less is allowed in the direction of resources. From a gender perspective the expected results of such a move are likely to be detrimental, affecting women's labor participation rates and overall career prospects, especially in the countries currently lacking the resources to substitute household provisioning either with market or state provided services. The risk of adverse, unintended consequences is present not only in the specter of reform failure, but also in the intense political backlash against the EU, already evident in the results of the 
latest round of European elections. Unfortunately, the more promising solutions at the moment also seem to be the least politically feasible. 